\title{
Organic-Inorganic Perovskite for Highly Efficient Tandem Solar Cells
}

\author{
Ik Jae Park ${ }^{1}$ and Dong Hoe Kim ${ }^{2, \dagger}$ \\ ${ }^{1}$ Department of Materials Science \& Engineering, Seoul National University, Seoul 08826, Korea \\ ${ }^{2}$ Department of Nanotechnology \& Advanced Materials Engineering, Sejong University, Seoul 05006, Korea
}

\section{고효율 적층형 태양전지를 위한 유무기 페로브스카이트}

\author{
박익재, 김동회 ${ }^{\dagger}$ \\ ${ }^{1}$ 서울대학교 재료공학부, ${ }^{2}$ 세종대학교 나노신소재공학과
}

(Received June 10, 2019; Accepted June 17, 2019)

\begin{abstract}
s
To overcome the theoretical efficiency of single-junction solar cells (> $30 \%$ ), tandem solar cells (or multi-junction solar cells) is considered as a strong nominee because of their excellent light utilization. Organic-inorganic halide perovskite has been regarded as a promising candidate material for next-generation tandem solar cell due to not only their excellent optoelectronic properties but also their bandgap-tune-ability and low-temperature processpossibility. As a result, they have been adopted either as a wide-bandgap top cell combined with narrow-bandgap silicon or $\mathrm{Culn}_{x} \mathrm{Ga}_{(1-x)} \mathrm{Se}_{2}$ bottom cells or for all-perovskite tandem solar cells using narrow- and wide-bandgap perovskites. To successfully transition perovskite materials from for single junction to tandem, substantial efforts need to focus on fabricating the high quality wide- and narrow-bandgap perovskite materials and semi-transparent electrode/recombination layer. In this paper, we present an overview of the current research and our outlook regarding perovskite-based tandem solar technology. Several key challenges discussed are: 1) a wide-bandgap perovskite for top-cell in multi-junction tandem solar cells; 2) a narrow-bandgap perovskite for bottom-cell in allperovskite tandem solar cells, and 3) suitable semi-transparent conducting layer for efficient electrode or recombination layer in tandem solar cells.
\end{abstract}

Keywords: Perovskite, Perovskite Solar Cells, Wide-bandgap perovskite, Narrow-bandgap perovskite, Tandem Solar Cells, Multi-junction Solar Cells, 

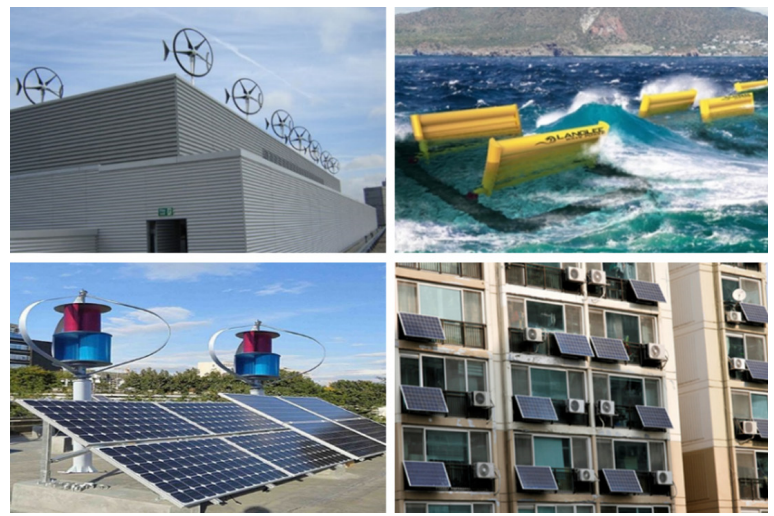

Fig. 1. Rooftop wind turbine, wave turbine, 소규모 solar farm과 wind turbine, 아파트용 소규모 solar panel등 다양한 형태의 국소적 에너지 생산 발전 설비

\section{1. 서론}

현대사회가 발전을 거듭하면서 에너지 소비 수요는 매 년 빠르게 증가하고 있다. 에너지 수요를 보다 효율적으 로 해결하기 위하여 기존의 화석 연료 기반의 화력 발전, 원자력 발전, 수력이나 풍력 등의 재생 에너지 발전 등의 거대한 발전 설비 기반의 거점 발전에서 자가 발전을 겸 하는 형태의 에너지 생산의 패러다임 변화가 빠르게 일어 나고 있다. 오늘날 Fig. 1에서 보는 것과 같이 풍력 발전, 해양소수력발전, 태양광발전 등 다양한 재생 에너지 기반 의 소규모 발전은 국소적 에너지 생산 패러다임을 이끄는
주요 에너지 자원으로 주목받고 있다. 그러나 이러한 소 규모 발전을 이끄는 재생 에너지원은 설치에 있어서 지리 적, 기후적 영향이 크기 때문에 보급에 한계를 가지고 있 다. 이 중에서 태양광발전의 경우, 지구 어디에도 전부 도 달하며, 동시에 무한히 공급 가능한 에너지 자원으로 대 규모 태양광발전 농장(Solar Farm)에서부터 우리 주변 의 아파트나 주택 등 보편적인 주거 환경에 초소규모 독 립적인 형태까지 널리 보급되어 있다. 그 결과, 태양광발 전은 현재 전 세계 에너지 수요의 $2.5 \%$ 의 전기를 보급하 고 있다. ${ }^{1)}$

이처럼 태양광발전의 형태가 다양화됨에 따라서 스마 트기기 전력 공급용 초박형 휴대용 태양광 패널, 무인 비 행체나 전기자동차 등의 전력 공급용 초경량 패널이나 오 지 탐험 및 군사용 초경량 유연 포터블 패널 등 새로운 시 장의 요구도 점차 증가하고 있다. 그러나 기존의 태양광 발전은 1970년대부터 개발되어 상용화된 실리콘 기반의 태양전지로, 공정의 특성상 초경량성, 휴대성 그리고 유 연성 등을 확보하기가 쉽지 않다. 기술적으로도 성숙 단 계에 접어들면서 최고 효율의 증가 속도가 줄어들고 있 다. (Fig. 2) ${ }^{2)}$ 또한 실리콘 소재 단가 및 공정 단가 측면 에서 위와 같은 다양한 시장의 요구에 대응하기 위해서는 저렴한 생산단가와 고효율을 확보할 수 있는 태양전지 기 술이 필요하다.

흡수대역이 다른 두 개 이상의 태양전지를 사용하여 단

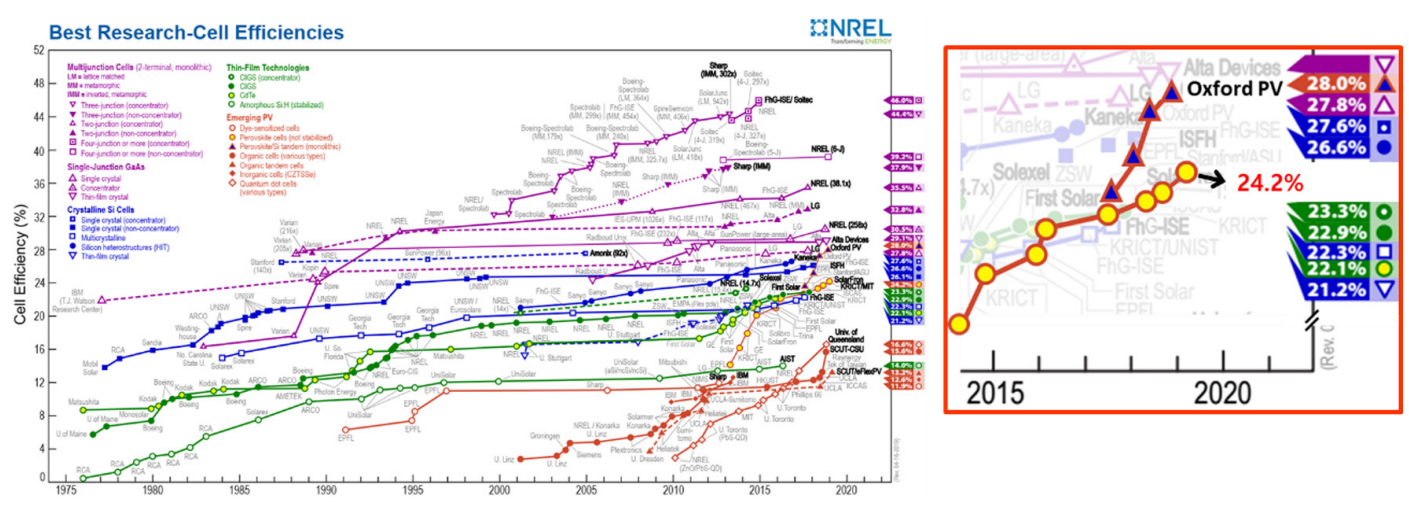

Fig. 2. 2019년 4월 태양전지 인증 효율 그래프.' 노란색 원형 마크는 페로브스카이트 박막 태양전지의 인증 효율, 파란색 삼각형 그래프는 페 로브스카이트-실리콘 적층형 태양전지의 인증 효율 
파장 가시광부터 적외선까지 우수한 광전 변환 특성을 확 보한 다중 접합 태양전지 소자는 이러한 문제점과 시장의 요구를 충족시켜주는 하나의 방향으로써 지속적으로 관 심을 받아오고 있었다. Fig. 2에 나와있는 태양전지별 인 증 효율 그래프를 보면 현재 $30 \%$ 이상의 광전 변환 효율 은 모두 다중 접합 태양전지에서 나온 결과이다. ${ }^{2}$ 하지만 현재까지 다중 접합 태양전지는 소재 및 공정에 있어서 높은 생산 단가를 지니고 있기 때문에 우리의 일상생활에 적용되기에는 해결해야 할 많은 어려움이 있다. 따라서 기존의 태양전지에 적은 비용으로 다중 접합 태양전지를 제작하거나 혹은 완전히 새롭게 용액 공정 혹은 저비용 진공 공정 등을 이용한 다중 접합 태양전지를 제작할 수 있는 소재와 공정에 대한 개발이 필요하다.

2009년 처음 새로운 광흡수체로 보고된 유기-무기 할 라이드 페로브스카이트 소재(이하, 페로브스카이트)는 이러한 부분을 충족시켜줄 수 있는 높은 가능성을 지니고 있다. ${ }^{3)}$ 전고체형 다결정 박막 태양전지(all-solid-state polycrystalline solar cells) 형태로 적용되는 페로브스 카이트 소재는 보고된 지 8년 만에 박막 태양전지에서는 가장 높은 $24.2 \%$ 의 인증 효율을 보이면서 수년간 머물러 있던 차세대 태양전지 연구에 돌파구를 보여주었다. ${ }^{2)}$ 또 한 소재의 특성상 동일한 페로브스카이트 결정구조에서 다양한 조성으로 합성할 수 있는데, 이때 조성에 따라 밴 드갭이 변하기 때문에 이는 다중 접합 소자를 형성하는데 있어서 반드시 요구되는 특성이라고 볼 수 있다. 해당 소 재는 사용되는 원료의 생산 단가 측면과 용액 공정 기반

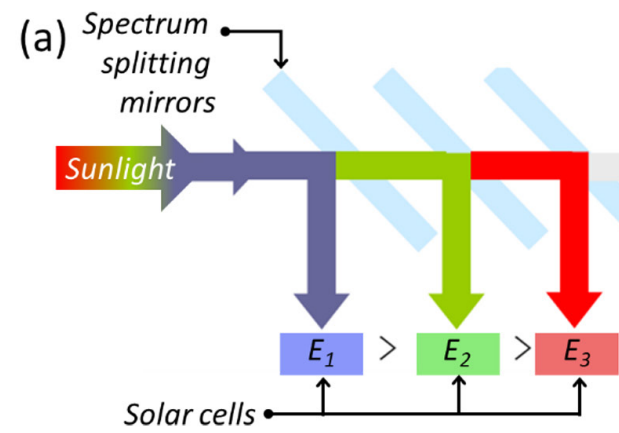

의 낮은 공정 비용 임에도 높은 효율을 나타내기 때문에 전력 생산 단가 측면에서 다중 접합 태양전지에 적용되기 적합하다. 또한 최근 대면적 프린팅 기술에 대한 연구도 활발히 진행됨으로써 실험실 단위의 연구에서 벗어나 상 용화 단계로 도약하고 있다. ${ }^{4)}$ 그 결과, 최근 3년 동안 페 로브스카이트 소재는 기존의 태양전지 혹은 페로브스카 이트만을 이용하여 다중 접합 태양전지 소자 제작에 적용 되었고, 우수한 효율을 기록하였다. 실리콘-페로브스카 이트 태양전지는 $28 \%$ 의 인증 효율을 기록하고 있는데 이 는 저비용 기반의 다중 접합 소자에서는 가장 높은 인증 효율이다. ${ }^{2)}$

이와 같이 페로브스카이트 태양전지 소재가 단위 소자 에서 나아가 다중 접합 소자로 적용되기 시작함으로써 $30 \%$ 이상의 저비용 고효율 소자 구현에 한 발 더 다가가 있는 상황이다. 본 글에서는 페로브스카이트 소재를 기반 으로 한 고효율 다중 접합 태양전지 소자에 대한 최근 동 향을 요약하고자 한다.

\section{2. 다중 접합 태양전지와 유무기 폐로브스카이트 기반 다중 접합 태양전지 현황}

\section{1 다중 접합 태양전지}

태양전지가 $30 \%$ 이상의 고효율 광전 변환 효율을 얻기 위해서는 자외선부터 적외선에 이르는 지구로 입사된 태 양빛의 모든 파장 대역을 활용할 수 있어야 한다. 광 흡수 대역을 넓히기 위한 방향으로는 입사된 빛을 파장별 분리 (b)

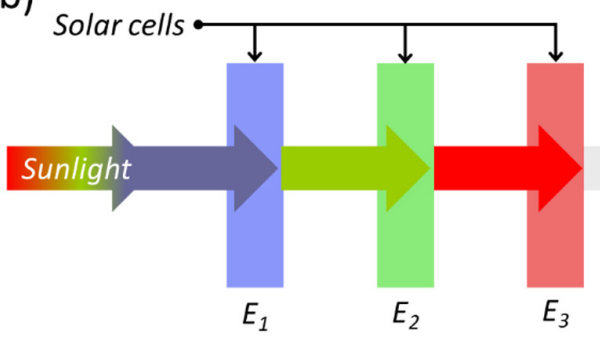

Fig. 3. 태양빛 활용을 극대화하기 위한 다중 접합 태양전지 개념도. ${ }^{5)}$ (a) 파장 분리형, (b) 적층형 다중 접합 태양전지 
가 가능한 광학 거울을 이용하여 여러 개의 특정 파장대 역 빛으로 분리한 뒤에 해당 파장대역의 광전 변환 효율 이 가장 높은 태양전지를 배치하는 파장 분리 방법(Fig. 3-(a))과 단파장에서부터 장파장에 이르는 입사되는 빛 의 파장의 세기에 따라 광흡수-전기 변환 특성이 우수한 태양전지를 흡수 대역이 높은 순서에 따라서 배치하는 적 층 방법(Fig. 3-(b))이 있다. ${ }^{5)}$ Fig. 3-(a)에서 설명된 파 장 분리형 다중 접합 태양전지의 경우, 기존의 태양전지 기술에서 빛의 파장대역을 분리시킬 광학계만 추가함으 로써 광 흡수 대역을 증가시킬 수 있으므로 상대적으로 기술 장벽이 낮다는 장점이 있다. 그러나 다양한 광학계 를 사용함으로써 제작과 구조가 복잡하고 광학 파트의 추 가적인 비용이 발생하게 된다. 또한 대면적으로 제작이 어렵고 대량 생산에 한계가 있다. 이에 비해 Fig. 3-(b) 에서 설명하고 있는 적층형 방식의 다중 접합 태양전지는 추가적인 광학계 없이 흡수대역이 다른 여러 태양전지를 흡수 파장에 따라서 순차적으로 배열하여 전기를 생산한 다. 각 태양전지에서 흡수되고 남은 빛을 다음 태양전지 소자로 투과시켜서 보내야 하기 때문에 각각의 태양전지 가 반투명 특성을 지녀야 한다. 따라서 빛을 손실시킬 수 있는 각각의 태양전지에 사용되는 투명 전도성 기판을 최 소화 · 초박막화해야 하며, 이후 설명하겠지만 형태에 따 라서 소자가 직접적으로 합쳐진 형태를 지니고 있기 때문 에 전극 및 연속하는 태양전지 소자를 형성하는 공정에 있어서 앞서 만들어진 소자에 발생할 수 있는 공정 상의 손상 등을 반드시 고려해야만 한다. 따라서 Metalorganic chemical vapor deposition (MOCVD)나 Molecularbeam epitaxy $(\mathrm{MBE})$ 등의 박막 진공 공정 기반으로 제 작이 이뤄지고 있으나 까다로운 공정, 높은 비용 및 대면 적화가 어렵다는 문제점이 있다. 그러나, 앞서 언급한 바 와 같이 단일 소재만을 이용하여 태양전지 제작 시, 태양 광 활용의 한계에 따른 이론적인 효율 한계가 있기 때문 에 저비용 고효율 재생에너지 활용이라는 측면에 있어서 다중 접합 태양전지 개발은 많은 관심을 받으며 연구가 이뤄지고 있다. 그 중에서도 전력 생산의 경제적인 측면 과 효율적인 측면을 복합적으로 고려했을 때, 다중 접합 태양전지에 대한 연구는 광학계 등의 추가적인 비용이 덜 고려되며 별도의 전극 공정을 최소화할 수 있는 적층 방 법을 기반으로 한 방향을 중심으로 이뤄지고 있다.

위에서 설명한 바와 같이, 적층형 다중 접합 태양전지 (이하 적층형 태양전지(Tandem solar cell))는 입사되는 빛에 수직한 방향으로 흡수대역이 다른 태양전지를 흡수 파장의 범위가 좁은 것에서부터 넓은 순서로 배열하여 소 자를 형성하게 된다. 일반적으로 태양광을 흡수하는 빛 흡수층 소재(light absorber material)의 밴드갭을 통하 여 소자에 입사된 태양광의 흡수대역을 조절한다. 따라서 밴드갭이 넓은 빛 흡수층(wide bandgap absorber)을 기 반으로 태양전지를 제작하여 단파장 영역의 빛만을 사용 하여 전기를 얻는다. 일반적으로 입사된 빛을 가장 위쪽 에서 먼저 흡수하기 때문에 상부 소자(top cell)라고 부른 다. 이후에 위치한 태양전지는 상부 소자를 통과한 상대 적으로 장파장 대역의 가시광과 적외선으로 이뤄진 태양

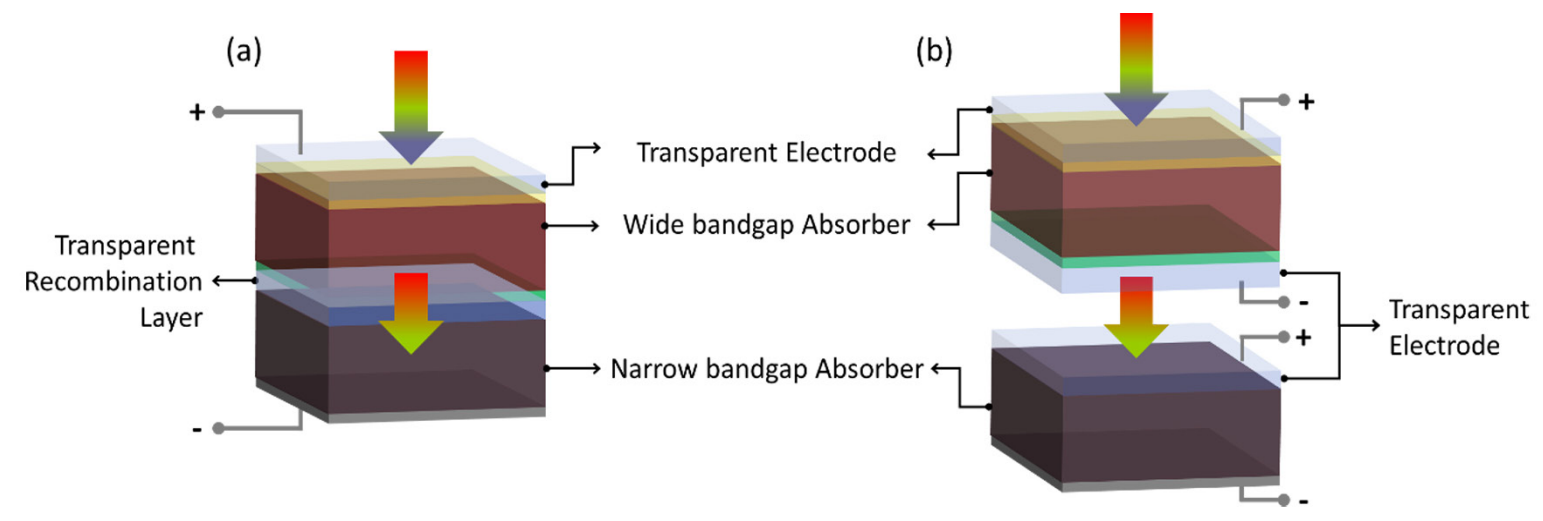

Fig. 4. 적층형 태양전지의 구조, (a) 2 터미널, (b) 4 터미널 전극 형태 


\section{특 집 부막ㄱㅈㅐ, 김동회}

광을 흡수한다. 이를 효과적으로 활용하기 위하여 일반적 으로 $1.0 \sim 1.3 \mathrm{eV}$ 의 밴드갭이 좁은 빛 흡수층(narrow bandgap absorber) 소재가 태양전지에 적용된다. 상부 소자 다음에 오는 소자이기 때문에 일반적으로 하부 소자 (bottom cell)라고 한다. 적층형 태양전지의 경우 소자의 전극이 결합된 형태에 따라서 Fig. 4와 같이 크게 두 가 지로 구분을 지을 수 있다. 먼저, 서로 다른 흡수대역을 가지는 상부 소자와 하부 소자 사이에 투명한 전자-정공 재결합층으로 연결되어 두 가지 전극을 지닌 단일 소자의 형태의 monolithic한 결합으로 이뤄진 2 터미널 (2-terminal, 2-T) 적층형 태양전지이다. (Fig. 4-(a)) Fig. 4-(b)에서 소개된 다른 형태는 상부 소자의 전극이 모두 투명 전극으로 이뤄져 있고, 하부 소자의 전극 역시
빛을 받을 수 있도록 투명 전극이 위쪽으로 형성되어 두 소자를 물리적으로 포개 놓은 형태의 각각의 전극이 독립 적으로 존재하는 4 터미널(4-terminal, 4-T) 적층형 태 양전지이다.

2 터미널 적층형 태양전지의 경우, 중간에 존재하는 전 자-정공 재결합층을 통하여 두 소자가 직렬로 연결된 형 태로 별도의 전극 공정을 필요로 하지 않고 상부 소자와 하부 소자로 빛이 투과되는 동안 전자-정공 재결합층만 을 지나기 때문에 빛 손실이 매우 적어 우수한 빛 활용 특 성을 지니고 있다고 볼 수 있다. 그러나 재결합층을 통하 여 전기적으로 상하부 소자가 직렬 연결되어(seriescoupling) 있는 형태이기 때문에, 상부 또는 하부 소자에 서 재결합을 위해 제공되는 전하와 정공의 양이 같아야 (a)

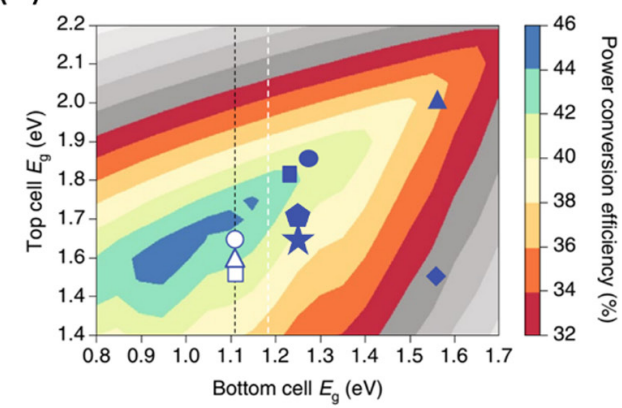

(b)

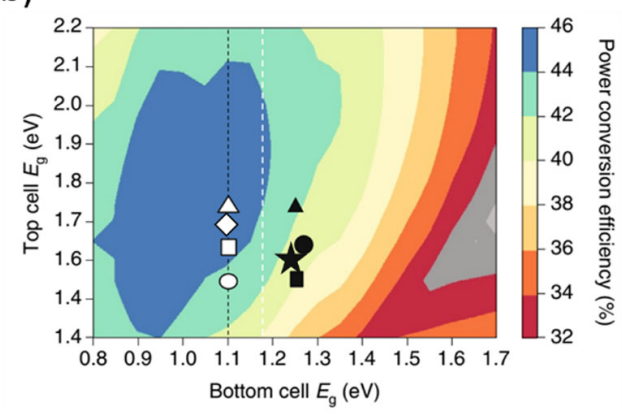

(d)

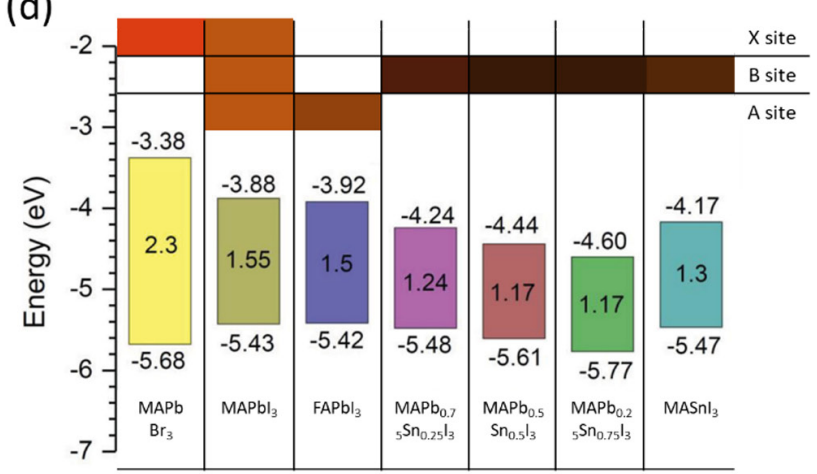

Fig. 5. 적층형 태양전지에서 상부 소자와 하부 소자에 적용된 광흡수층의 밴드갭 조합에 따른 이론 효율과 유무기 할라이드 페로브스카이트 의 결정 구조 및 조성에 따른 밴드갭 특성. (a) 2-터미널, (b) 4-터미널 구조의 적층형 태양전지. ${ }^{6)}$ 각 상하 소자의 경우 해당 밴드갭에 서 최적의 두께에서 얻을 수 있는 최대 효율을 기반으로 모델링이 이루어졌으며, 효율 등고선 그래프에서 회색 영역은 단일 빛 흡수 물질을 이용해서 얻을 수 있는 이론 최대 효율인 32\%보다 낮은 영역으로 적층형 태양전지 형성을 통하여 얻어지는 효율이 전혀 없 는 구간을 의미. 하얀색 점선은 현재 만들 수 있는 가장 좁은 밴드갭의 페로브스카이트 태양전지를 의미. 검정색 점선은 $1.1 \mathrm{eV}$ 밴드 갭의 실리콘 또는 CIGS 태양전지. 칠해진 기호의 경우, 현재 보고된 페로브스카이트-페로브스카이트 기반의 적층형 태양전지의 밴 드갭 조합. 하얀 색 기호의 경우 현재까지 보고된 페로브스카이트-실리콘 태양전지 밴드갭 조합. (효율은 Table 1에 표기) (c) 페로브 스카이트 결정 구조 및 일반적으로 사용되는 조성 (d) A, B, X에 위치하는 조성에 따른 형성된 페로브스카이트의 밴드갭 변화와 이에 따른 박막의 색상 변화 방향 
Tables 1. 페로브스카이트-이종(Hetero) 혹은 페로브스카이트-페로브스카이트 기반 적층형 태양전지 효율

\begin{tabular}{|c|c|c|c|c|c|}
\hline 결합 형태 & 하부 소자 ( $\mathrm{Si}, \mathrm{CIGS}$, 페로브스카이트) & 상부 소자 (페로브스카이트) & 효율 & Fig. 5에 표기된 기호 & 참고문헌 \\
\hline $4-\mathrm{T}$ & $\mathrm{IBC} \mathrm{c}-\mathrm{Si}^{\mathrm{a}}$ & $\begin{array}{c}\mathrm{FA}_{0.75} \mathrm{MA}_{0.15} \mathrm{Cs}_{0.10} \mathrm{Rb}_{0.05}\left(\mathrm{I}_{0.66} \mathrm{Br}_{0.33}\right)_{3} \\
(1.63 \mathrm{eV})\end{array}$ & 26.4 & $\square$ & 15) \\
\hline $4-\mathrm{T}$ & $\mathrm{SHJ}$ c-Sib & $\begin{array}{c}\mathrm{MAPbI}_{3} \\
(1.55 \mathrm{eV}) \\
\end{array}$ & 25.2 & ○ & 24) \\
\hline $4-\mathrm{T}$ & $\mathrm{SHJ}$ c-Si & $\begin{array}{c}\mathrm{FA}_{0.83} \mathrm{CS}_{0.17} \mathrm{~Pb}\left(\mathrm{I}_{0.6} \mathrm{Br}_{0.4}\right)_{3} \\
(1.74 \mathrm{eV})\end{array}$ & 19.8 & $\triangle$ & 18) \\
\hline $4-\mathrm{T}$ & $\mathrm{TI} \mathrm{mc}-\mathrm{Si}^{\mathrm{c}}$ & $\begin{array}{c}\mathrm{MAPbI}_{3} \\
(1.55 \mathrm{eV}) \\
\end{array}$ & 17.0 & o & 39) \\
\hline $4-\mathrm{T}$ & CIGS & $\begin{array}{c}\mathrm{PEA}_{0.02} \mathrm{Cs}_{0.15} \mathrm{MA}_{0.2} \mathrm{FA}_{0.65} \mathrm{PbI}_{2.4} \mathrm{Br}_{0.6} \\
(1.68 \mathrm{eV})\end{array}$ & 25.9 & $\diamond$ & 9) \\
\hline $2-\mathrm{T}$ & $\mathrm{c}-\mathrm{Si}$ & $\begin{array}{c}\text { Perovskite } \\
(-\mathrm{eV})\end{array}$ & 28.0 & - & 2) \\
\hline $2-\mathrm{T}$ & $\mathrm{SHJ}$ c-Si & $\begin{array}{c}\mathrm{FA}_{0.83} \mathrm{MA}_{0.17} \mathrm{PbI}_{2.5} \mathrm{Br}_{0.5} \\
(1.66 \mathrm{eV})\end{array}$ & 25.5 & 0 & 7) \\
\hline $2-\mathrm{T}$ & $\mathrm{SHJ}$ c-Si & $\begin{array}{c}\mathrm{FA}_{0.83} \mathrm{CS}_{0.17} \mathrm{~Pb}\left(\mathrm{I}_{0.83} \mathrm{Br}_{0.17}\right)_{3} \\
(1.63 \mathrm{eV})\end{array}$ & 23.6 & ○ & 19) \\
\hline $2-\mathrm{T}$ & $\mathrm{n}$-형 $\mathrm{HJ} \mathrm{c}-\mathrm{Si}^{\mathrm{d}}$ & $\mathrm{Cs}_{0.07} \mathrm{Rb}_{0.03} \mathrm{FA}_{0.765} \mathrm{MA}_{0,135} \mathrm{~Pb}\left(\mathrm{I}_{0.85} \mathrm{Br}_{0.15}\right)_{3}(1.62 \mathrm{eV})$ & 22.5 & ○ & 40) \\
\hline $2-\mathrm{T}$ & $\mathrm{SHJ}$ c-Si & $\begin{array}{c}\mathrm{Cs}_{0.19} \mathrm{MAA}_{0.81} \mathrm{PbI}_{3} \\
(1.58 \mathrm{eV})\end{array}$ & 22.0 & $\triangle$ & 41) \\
\hline $2-\mathrm{T}$ & SHJ c-Si & $\begin{array}{c}\mathrm{MAPbI}_{3} \\
(1.55 \mathrm{eV}) \\
\end{array}$ & 21.2 & $\square$ & 23) \\
\hline $2-\mathrm{T}$ & $\mathrm{SHJ}$ c-Si & $\begin{array}{l}\mathrm{MAPbI}_{3} \\
(1.55 \mathrm{eV})\end{array}$ & 18.1 & $\square$ & 42) \\
\hline $2-\mathrm{T}$ & n-형 HJ c-Si & $\begin{array}{r}\mathrm{MAPbI}_{3} \\
(1.55 \mathrm{eV}) \\
\end{array}$ & 13.7 & $\square$ & 22) \\
\hline $2-\mathrm{T}$ & CIGS & $\begin{array}{c}\mathrm{Cs}_{0,09} \mathrm{FA}_{0.77} \mathrm{MA}_{0.14} \mathrm{~Pb}\left(\mathrm{I}_{0.86} \mathrm{Br}_{0,14}\right)_{3} \\
(1.59 \mathrm{eV})\end{array}$ & 22.4 & $\Delta$ & 8) \\
\hline $4-\mathrm{T}$ & $\begin{array}{c}7 \% \text { GuaSCN }-\mathrm{FA}_{0.6} \mathrm{MA}_{0.4} \mathrm{Sn}_{0.6} \mathrm{~Pb}_{0.4} \mathrm{I}_{3} \\
(1.25 \mathrm{eV})\end{array}$ & $\begin{array}{c}\mathrm{Cs}_{0.05} \mathrm{FA}_{0.80} \mathrm{MA}_{0.15} \mathrm{~Pb}\left(\mathrm{I}_{0.85} \mathrm{Br}_{0.15}\right)_{3} \\
(1.63 \mathrm{eV})\end{array}$ & 25.0 & $\star$ & 12) \\
\hline $4-\mathrm{T}$ & $\begin{array}{c}\mathrm{FA}_{0.6} \mathrm{MA}_{0.4} \mathrm{Sn}_{0.60} \mathrm{~Pb}_{0.40} \mathrm{I}_{3} \\
(1.25 \mathrm{eV})\end{array}$ & $\begin{array}{c}\mathrm{FA}_{0.8} \mathrm{Cs}_{0.2} \mathrm{~Pb}\left(\mathrm{I}_{0.7} \mathrm{Br}_{0.3}\right)_{3} \\
(1.75 \mathrm{eV})\end{array}$ & 22.9 & $\Delta$ & 43) \\
\hline $4-\mathrm{T}$ & $\begin{array}{c}\mathrm{FA}_{0.75} \mathrm{Cs}_{0.25} \mathrm{Sn}_{0.5} \mathrm{~Pb}_{0.5} \mathrm{I}_{3} \\
(1.27 \mathrm{eV})\end{array}$ & $\begin{array}{r}\mathrm{MAPbI}_{3} \\
(1.55 \mathrm{eV}) \\
\end{array}$ & 21.0 & - & 33) \\
\hline $4-\mathrm{T}$ & $\begin{array}{c}\mathrm{FA}_{0.75} \mathrm{Cs}_{0.25} \mathrm{Sn}_{0.5} \mathrm{~Pb}_{0.5} \mathrm{I}_{3} \\
(1.27 \mathrm{eV})\end{array}$ & $\begin{array}{c}\mathrm{FA}_{0.83} \mathrm{Cs}_{0.17} \mathrm{~Pb}_{\left(\mathrm{I}_{0.83} \mathrm{Br}_{0.17}\right)_{3}} \\
(1.63 \mathrm{eV})\end{array}$ & 20.3 & $\bullet$ & 10) \\
\hline $2-\mathrm{T}$ & $\begin{array}{c}\mathrm{FA}_{0.75} \mathrm{Cs}_{0.25} \mathrm{Sn}_{0.5} \mathrm{~Pb}_{0.5} \mathrm{I}_{3} \\
(1.27 \mathrm{eV})\end{array}$ & $\begin{array}{c}\mathrm{FA}_{0.6} \mathrm{Cs}_{0.3} \mathrm{DMA}_{0.1} \mathrm{PbI}_{2.4} \mathrm{Br}_{0.6} \\
(1.70 \mathrm{eV})\end{array}$ & 23.1 & $\bullet$ & 11) \\
\hline $2-\mathrm{T}$ & $\begin{aligned} 7 \% \text { GuaSCN}-\mathrm{FA}_{0.6} \mathrm{MA}_{0.4} \mathrm{Sn}_{0.6} \mathrm{~Pb}_{0.4} \mathrm{I}_{3} \\
(1.25 \mathrm{eV})\end{aligned}$ & $\begin{array}{c}- \\
(1.75 \mathrm{eV}) \\
\end{array}$ & 23.1 & $\star$ & 12) \\
\hline $2-\mathrm{T}$ & $\begin{array}{c}\mathrm{MASn}_{0.5} \mathrm{~Pb}_{0.5} \mathrm{I}_{3} \\
(1.22 \mathrm{eV})\end{array}$ & $\begin{array}{c}\mathrm{MA}_{0.9} \mathrm{Cs}_{0.1} \mathrm{~Pb}\left(\mathrm{I}_{0.6} \mathrm{Br}_{0.4}\right)_{3} \\
(1.82)\end{array}$ & 18.5 & - & 44) \\
\hline $2-\mathrm{T}$ & $\begin{aligned} \mathrm{FA}_{0.75} \mathrm{Cs}_{0.25} \mathrm{Sn}_{0.5} \mathrm{~Pb}_{0.5} \mathrm{I}_{3} \\
(1.27 \mathrm{eV})\end{aligned}$ & $\begin{array}{c}\mathrm{FA}_{0.83} \mathrm{Cs}_{0.17} \mathrm{~Pb}\left(\mathrm{I}_{0.50} \mathrm{Br}_{0.50}\right)_{3} \\
(1.85 \mathrm{eV})\end{array}$ & 17.0 & $\bullet$ & 10) \\
\hline $2-\mathrm{T}$ & $\begin{array}{c}\mathrm{MAPbI}_{3} \\
(1.55 \mathrm{eV}) \\
\end{array}$ & $\begin{array}{c}\mathrm{FA}_{0.85} \mathrm{Cs}_{0.15} \mathrm{~Pb}_{\left(\mathrm{I}_{0.30} \mathrm{Br}_{0.70}\right)_{3}} \\
(2.00 \mathrm{eV})\end{array}$ & 18.1 & $\Delta$ & 45) \\
\hline $2-\mathrm{T}$ & $\begin{array}{r}\mathrm{MAPbI}_{3} \\
(1.55 \mathrm{eV}) \\
\end{array}$ & $\begin{array}{r}\mathrm{MAPbI}_{3} \\
(1.55 \mathrm{eV}) \\
\end{array}$ & 7.0 & $\bullet$ & 46) \\
\hline
\end{tabular}

a IBC c-Si: interdigitated back contact solar cells, b SHJ c-Si: silicon heterojunction solar cells, c TI mc-Si: low grade multicrystalline silicon solar cells, d HJ c-Si: homo-junction solar cells

각 소자의 광전 변환 효율의 손실을 최소화할 수 있다. 따 라서 상하부 소자가 흡수하고 생성하는 전류를 조절하는 전류 매칭(current matching)이 매우 중요하다. 4 터미 널 적층형 태양전지는 2 터미널 적층형 소자와는 다르게 상하부 소자가 완벽하게 독립되어 각 소자에서 생성되는
전자-정공을 각각 수집하여 활용하기 때문에 전기적으 로 분리되어(decoupling) 되어 있다. 따라서 두 소자 사 이의 전류 매칭을 고려할 필요가 없으므로 상대적으로 적 층을 위한 밴드갭 선택에 있어서 유연성을 확보할 수 있 다. 그러나 빛이 상부 소자를 지나 하부 소자로 들어가는 
과정에서 상부 소자에 형성되어 있는 투명 전극과 상부 소자와 하부 소자 사이에 물리적으로 존재하는 공기 또는 연결층에서 발생하는 원치 않는 기생 흡수(parasitic absorption)이나 경계에서의 반사(reflection at the interface)로 인하여 빛 손실이 발생하게 된다. 따라서 4 터미널 적층형 태양전지는 두 상하부 소자 사이의 빛 손 실을 얼마나 최소화하는지가 적층형 태양전지의 효율을 결정하는데 큰 영향을 미친다.

\section{2 적층형 태양전지의 이론 효율 및 페로브스카이트 소재의 적용 현황}

Fig. 5의 (a)와 (b)는 이중 적층형 태양전지를 구성하는 상부 소자와 하부 소자에 적용된 빛 흡수 소재의 밴드갭 조합과 2 터미널(Fig. 5-(a)), 4 터미널(Fig. 5-(b)) 형 태에 따른 이론 효율을 보여주는 그래프이다. Fig. 5-(a) 에서 나타나 듯, 2 터미널 구조의 경우 4 터미널 구조 대 비 고효율을 얻을 수 있는 밴드갭 조합이 매우 제한적이 다. 이는 소자의 구조적인 특성에 의해 기인한 것으로써, 2 터미널 구조의 경우 전자-정공 재결합 시의 손실을 최 소화하기 위하여 상부 소자와 상부 소자를 지나고 남은 빛만으로 전류를 생성하는 하부 소자에서 생성된 각각의 전류 값이 일치하는 전류 매칭이 반드시 이뤄져야 하기 때문에 흡수되는 파장의 영역을 결정하는 빛 흡수층의 밴 드갭이 효율에 민감한 영향을 끼친다. 그에 비해 4 터미 널 구조는 전기적으로 상부 소자와 하부 소자가 독립적이 기 때문에 전류 매칭을 할 필요가 없다. 따라서 적층 구조 형성을 통한 효율 향상 효과를 구현할 수 있는 밴드갭 조 합 관용도가 훨씬 높다고 볼 수 있다. 4 터미널 구조는 밴 드갭에 따른 적층 소자 경향 등을 확인하는 기본 실험 (prototype test)로써 활용도가 높을 수 있으나 4 터미널 전극 형성을 위한 추가적인 투명 전극층 및 두 소자 사이 의 물리적인 간격 등에서 발생하는 빛 흡수, 반사 또는 손 실은 고효율 구현에 있어서 제약으로 작용한다.

고효율 적층형 태양전지를 구현하기 위하여 좀 더 자세 하게 이중 접합 적층형 태양전지의 이론 효율 그래프를 Fig. 5-(a)와 (b)를 통하여 살펴보면 상부 소자가 1.5$1.8 \mathrm{eV}$ 의 밴드갭 소재를 기반으로 하고, 하부 소자가
0.8-1.2 eV의 밴드갭 소재를 통하여 태양전지를 형성할 경우 최대 46\%에 이르는 높은 이론 효율을 얻을 수 있 음을 확인할 수 있다. ${ }^{6)}$ 이는, 단일 소재를 이용한 태양전 지가 얻을 수 있는 최대 이론 효율인 $32 \%$ 대비 이중 적층 화를 통하여 최대 약 $43 \%$ 의 추가적인 효율을 얻을 수 있 음을 의미한다. 따라서 적층형 태양전지 연구에 있어서 가장 중요한 것 중에 하나는 상부 소자 및 하부 전극에 사 용할 수 있는 적절한 밴드갭을 지니면서 광전 변환 효율 이 우수한 소재를 확보하는 것이다. 이에 $0.9-2.0 \mathrm{eV}$ 의 밴드갭의 다양한 소재를 바탕으로 한 태양전지들이 개발 되어 있다.

이미 1.0-1.3 eV의 좁은 밴드갭 영역에서는 $\mathrm{Si}$, $\mathrm{CuIn}_{\mathrm{x}} \mathrm{Ga}_{(1-\mathrm{x})} \mathrm{Se}_{2}$ (CIGS), 페로브스카이트 소재 등을 기 반으로 20-26\%에 이르는 태양전지들이 보고되었다. ${ }^{2}$, 7-12) 그 중에서도 실리콘 태양전지는 $1.1 \mathrm{eV}$ 의 밴드갭을 지니고 있으며 현재 태양전지 시장의 $90 \%$ 를 점유하고 있 고, 단일 접합 소자기준 $20 \%$ 이상의 고효율을 나타내기 때문에 페로브스카이트 기반 적층형 태양전지 소자의 하 부 소자로서 가장 주목받고 먼저 연구가 진행되어 왔다. 또한 현재까지도 가장 많은, 그리고 의미 있는 연구 결과 가 보고된 적층형 태양전지이다. CIGS 역시 $20 \%$ 이상의 광전변환효율이 가능하고 실리콘 대비 저렴한 박막형 태 양전지라는 점과 1.0-1.1 eV의 밴드갭을 갖기 때문에 페 로브스카이트와의 적층형 태양전지 소자 연구가 주목받 고 있다.

또한 1.6-2.0 eV의 넓은 밴드갭 영역에서 역시 $18 \%$ 이 상의 고효율의 태양전지 특성이 보고되어 있어, 이상적으 로는 $42 \%$ 까지의 고효율의 적층형 태양전지 소자를 구 현할 수 있다. 그러나 이를 구현하기 위해서 필요한 각각 의 소재들이 형성되는 온도나 제한적인 공정 분위기 등의 차이는 실제 적층형 태양전지 제작에 있어서 소재 선택에 많은 제약이 있다.

페로브스카이트 소재는 위에서 간단히 언급한 바와 같 이 이러한 점에서 뛰어난 장점을 가지고 있다. Fig. 5-(c) 은 페로브스카이트 소재에 결정 구조를 나타내고 있다. 페로브스카이트는 $\mathrm{ABX}_{3}$ 구조의 형태를 지닌 광물로써 1839년 러시아 광물 학자 Lev Perovski가 발견하면서 
소개되었다. 태양전지로 널리 사용되는 페로브스카이트 의 경우, $\mathrm{A}$ 양이온 위치에는 $\mathrm{CH}_{3} \mathrm{NH}_{3}{ }^{+}$(methylammonium, $\mathrm{MA}$ ), $\mathrm{HC}\left(\mathrm{NH}_{2}\right)_{2}{ }^{+}$(formamidinium, $\mathrm{FA}$ )등의 유 기 분자가, $\mathrm{B}$ 양이온 위치에는 $\mathrm{Pb}^{2+}, \mathrm{Sn}^{2+}$ 등의 원자가 위 치하며 X 위치의 음이온의 경우, $\mathrm{I}^{-}, \mathrm{Br}^{-}, \mathrm{Cl}^{-}$등의 할라 이드 음이온으로 구성되는 유기-무기 할라이드 페로브 스카이트를 의미한다. 2009년 Tsutomu Miyasaka 교수 팀이 $\mathrm{CH}_{3} \mathrm{NH}_{3} \mathrm{PbI}_{3}$ 페로브스카이트 물질을 이용하여 처 음으로 감응형 태양전지(sensitized-solar cells) 특성을 보고 한 이후, ${ }^{3)}$ 2012년 겨울부터 Henry Snaith 교수 팀 과 박남규 교수 연구 팀이 각각 전고체 태양전지(allsolid-state solar cell)에 해당 물질을 적용함으로써13,14) 페로브스카이트 물질 기반의 전고체 태양전지 연구가 시 작되어 현재에 이르기까지 폭발적인 연구가 이뤄졌고, 그 결과 위에서 설명한 바와 같이 $24.2 \%$ 의 박막 태양전지로 는 가장 높은 인증 효율을 확보하게 되었다. ${ }^{2)}$ 적층형 태 양전지에 적용하는데 있어서 페로브스카이트 태양전지 가 갖는 장점은 낮은 공정 온도와 조성의 유연성이다. 일 반적으로 페로브스카이트 박막을 형성하기 위해 용액 공 정이나 열기상 증착 진공 공정을 사용하게 되는데, 이 때 100-150도 사이의 매우 낮은 공정 온도가 가능하여 적층 공정을 확보하는데 매우 유리하게 작용한다. 더욱 주목할 점은 조성의 유연성에 있다. 페로브스카이트 물질은 $\mathrm{A}$, $\mathrm{B}, \mathrm{X}$ 위치에 여러 가지 분자나 원소가 복합적인 alloy를 형성할 수 있다. 따라서 A 위치에는 MA, FA 이외에도 $\mathrm{Cs}$ 또는 $\mathrm{Rb}$ 등의 무기 원소도 적용될 수 있으며, $\mathrm{X}$ 자리 에는 일반적으로 $\mathrm{I}$ 와 $\mathrm{Br}$ 을 섞는 형태로 널리 합성되고 있 다. 또한 최근에는 $\mathrm{B}$ 에 들어가는 $\mathrm{Pb}$ 원소를 $\mathrm{Pb}-\mathrm{Sn}$ alloy 형태로 바꾸는 연구도 활발히 진행 중이다. ${ }^{10-12)}$ alloy 형태로 형성된 페로브스카이트는 조성에 따라서 $1.2-2.3 \mathrm{eV}$ 의 폭넓은 밴드갭 범위를 가지게 된다. 이러 한 조성에 따른 밴드갭 변화 특성은 Fig. 5-(d)에 나타나 있다. 현재까지 이 범위 내에서 다양한 밴드갭과 조성에 서 $17 \%$ 이상의 페로브스카이트 태양전지 소자가 형성되 었고, 이는 기존의 태양전지 소재들과 다른 페로브스카이 트 소재만이 지닌 강점이라고 볼 수 있다. 따라서 페로브 스카이트 소재의 낮은 공정 온도와 탄력적인 밴드갭 조절
능력은 기존 태양전지와 헤테로(hetero) 적층형 태양전 지를 형성하는데 매우 적합하였고, 나아가서 $1.2-1.3 \mathrm{eV}$ 의 페로브스카이트와 1.7-1.8 eV의 페로브스카이트를 동시에 이용한 페로브스카이트-페로브스카이트 적층형 태양전지가 개발되었다. 현재, 보고되어 있는 페로브스 카이트-페로브스카이트 적층형 태양전지의 경우 $23.1 \%^{11,12}$ 와 $25 \%{ }^{12}$ 가 2 터미널과 4 터미널 구조에서 각 각 보고되어 있다. 또한 $\mathrm{Si}$ 또는 CIGS 등과 페로브스카 이트와의 헤테로 적층형 태양전지의 경우는, $\mathrm{Si}$-페로브 스카이트는 2 터미널에서는 28\% 4 , 4 터미널 구조로는 $26.4 \%$ 를 얻을 수 있었다. CIGS-페로브스카이트의 경 우에는 2 터미널과 4 터미널 구조에서 각각 $22.4 \%$ )와 $25.9 \%$ 의 효율이 보고되었다. 이러한 결과들은 $\mathrm{Si}$, CIGS, 페로브스카이트 단일 접합 소자의 최고 효율을 상회하여, 적층형 태양전지가 앞서 언급한 단일 소자의 효율 한계를 극복하는 효과적인 방법 중 하나임을 보여 준다.

이와 같이 페로브스카이트 소재를 기반으로 한 태양전 지는 상대적으로 최근 들어 주목받기 시작했음에도 불구 하고, 이종 혹은 동종 간의 두 가지 적층화에서 의미 있는 결과를 보여주었다. 그러나 아직까지는 상부 소자용 넓은 밴드갭 또는 하부 소자용의 좁은 밴드갭의 페로브스카이 트 소재 모두 주로 연구가 이뤄진 1.5-1.6 eV의 페로브 스카이트 소재와는 다른 특성을 가지고 있기에 상대적으 로 고품질의 막을 형성하거나 조성 변화에 따른 소재의 특성 변화 등에 있어서 많은 부분의 연구가 필요하다. 또 한 이종/동종 기반의 접합 태양전지를 형성함에 있어서 필수적인 재결합층에 대한 연구도 초기 단계이다. 해당 분야에서 현재까지 이뤄진 연구 결과를 통하여 앞으로 나 아가야 할 방향에 대하여 보다 자세한 이야기를 나눠보고 자 한다.

2 터미널 구조의 이중 접합 적층형 태양전지의 광전류 밀도(current density, $J_{\mathrm{sc}}$ )는 각각의 상부 소자와 하부 소자의 전류 중 낮은 광전류 밀도에 맞춰지기 때문에 상 부와 하부 소자가 각각 같은 광전류 밀도를 지녔을 때 접 합 태양전의 광전류 밀도가 가장 높게 된다. 우리는 이를 전류 매칭이라고 설명하였는데, 따라서 상부 소자 광흡수 
층의 밴드갭은 하부 소자 광흡수층의 밴드갭을 고려하여 가장 높은 전류 매칭값을 지니는 밴드갭으로 결정하게 된 다. 앞서 언급한 Fig. 5-(a)와 같이 2 터미널 구조에서 이 론상으로 고효율 상부 소자를 위한 페로브스카이트 광흡 수층의 최적 밴드갭은 $1.1 \mathrm{eV}$ 의 밴드갭을 지닌 실리콘 또 는 CIGS 하부 소자의 경우 약 $1.7 \mathrm{eV}$ 이며, $1.22-1.25 \mathrm{eV}$ 의 페로브스카이트 하부 소자의 경우 $1.8 \mathrm{eV}$ 가 요구된 다. ${ }^{6}$ 페로브스카이트-페로브스카이트 적층형 태양전지 의 경우, 실리콘 또는 CIGS의 경우와 다르게 투명전극이 증착된 유리기판 위에 제작이 가능하기 때문에 상부 투명 전극이 필요하지 않다. 소자 평가 시, 유리기판 방향으로 부터 태양광이 입사되기 때문에 넓은 밴드갭의 페로브스 카이트 상부 소자를 먼저 형성시킨 후 좁은 밴드갭의 하 부 소자를 제작하게 된다. 따라서 고효율 적층형 태양전 지를 구현하는데 있어서는 $1.7-1.8 \mathrm{eV}$ 밴드갭을 지닌 페 로브스카이트 형성 기술이 중요하다. ${ }^{10)}$

Fig. 5-(d)에서 나와있는 것처럼 페로브스카이트의 밴 드갭을 넓히는 방향의 조성 조절은 $\mathrm{ABX}_{3}$ 구조에서 $\mathrm{X}$ site의 할라이드 계열의 음이온을 치환하는 방식이 사용 된다. 현재 단일 접합 기준 가장 널리 사용되는 방법은 $\mathrm{Cs} / \mathrm{FA} / \mathrm{MA}$ triple 양이온 기반의 페로브스카이트 조성 에 $\mathrm{I}^{-}$이온을 $\mathrm{Br}^{-}$이온으로 치환하는 것이다. 이때, 1.70 $\mathrm{eV}$ 이상의 밴드갭을 갖기 위해 $\mathrm{I}^{-}$음이온 대비 $30 \%$ 이상 의 $\mathrm{Br}^{-}$음이온이 필요하다. 그러나 $\mathrm{I}-\mathrm{Br}$ alloy에서 $\mathrm{Br}$ 의 양이 일정 비율 이상으로 증가하게 되면 구동 조건 하에 서 I-Br alloy가 I가 풍부한 상과 $\mathrm{Br}$ 이 풍부한 상으로 빠 르게 이온 분리(ion segregation) 현상이 일어나 페로브 스카이트 결정이 매우 불안정해지고 이는 소자의 급격한 효율 감소로 이어진다. ${ }^{16,17)}$ 또한, 밴드갭이 커질수록 소 재의 밴드갭과 실제 소자의 개방 전압(Open circuit voltage, $\left.V_{\mathrm{oc}}\right)$ 차이인 전압 결핍 $\left(V_{\mathrm{oc}}\right.$ deficit, $\left.E_{\mathrm{g}} / \mathrm{q}-V_{\mathrm{oc}}\right)$ 이 커진다. ${ }^{17)}$ 많은 연구진들은 넓은 밴드갭을 지니면서 동시 에 광안정성 확보하고 전압 결핍을 최소화하여 고효율을 얻을 수 있는 I-Br alloy 형태의 페로브스카이트에 대한 연구를 진행하였고, 이에 대해서 소개를 하고자 한다.

\section{3. 상부 소자를 위한 유무기 폐로브스카이트}

\section{1 넓은 밴드갭 페로브스카이트 형성 및 페로브 스카이트/페로브스카이트 적층형 태양전지로의 적용}

I-Br 할라이드 이온 alloy 형태를 지닌 넓은 밴드갭의 페로브스카이트는 광 아래에서 매우 불안정한 결정 특성 을 보였고, 이는 alloy 내부에서 I가 풍부한 상과 $\mathrm{Br}$ 이 풍 부한 상으로 분리되었다. 따라서 I-Br alloy 형태의 넓은 밴드갭 페로브스카이트는 $\mathrm{Br}$ 의 사용을 줄이면서 동시에 결정 구조를 안정적으로 형성하는 방향의 연구가 활발하 게 진행된다. 2016년 영국 Oxford 대학의 Henry Snaith 교수진은 $1.75 \mathrm{eV}$ 밴드갭의 $\mathrm{MAPb}\left(\mathrm{I}_{0.6} \mathrm{Br}_{0.4}\right)_{3}$ 페로브스카 이트의 A site 자리를 무기 양이온인 $\mathrm{Cs}^{+}$으로 치환하여 $\mathrm{FA}_{0.83} \mathrm{CS}_{0.17} \mathrm{~Pb}\left(\mathrm{I}_{0.6} \mathrm{Br}_{0.4}\right)_{3}$ 을 형성하고 광 안정성을 확보하 였다. (Fig. 6-(a)) $)^{18)}$ 이를 통하여 A site와 X site를 복 합적으로 조절하여 밴드갭과 광안정성을 확보하는 연구 가 본격적으로 진행하게 되었고, 가장 최근에는 미국 National Renewable Energy Laboratory (NREL)의 Giles 박사와 Tomas 박사 연구팀은 A site에 부피가 큰 dimethylammonium $\left(\mathrm{DMA}^{+}\right)$과 $\mathrm{Cs}^{+}$를 조합하여 밴드 갭을 조절함으로써 동일한 $1.70 \mathrm{eV}$ 밴드갭에서 $\mathrm{I}-\mathrm{Br}$ alloy 내의 $\mathrm{Br}$ 양을 40\%에서 20\%로 감소하며 높은 광 구 동 안정성을 확보한 페로브스카이트 조성을 확보하게 된 다. Fig. 6-(b) $)^{11)}$ 해당 연구팀은 이를 $1.27 \mathrm{eV}$ 밴드갭을 지닌 $\mathrm{FA}_{0.75} \mathrm{Cs}_{0.25} \mathrm{Sn}_{0.5} \mathrm{~Pb}_{0.5} \mathrm{I}_{3}$ 페로브스카이트와 적층하여 일반적인 투명전도성 유리기판에서 $23.1 \%$ 의 페로브스카 이트-페로브스카이트 적층형 태양전지를 구현하였다. 나아가, 동일한 구조를 유연 기판에 적용하여 $21.3 \%$ 의 높은 유연 적층형 태양전지를 구현하였다.

또한 NREL의 Kai 박사팀과 세종대 김동회 교수 공동 연구팀은 $1.68 \mathrm{eV}$ 의 넓은 밴드갭의 페로브스카이트 조성 을 그대로 유지한 채, 2차원(2-dimension, 2D) 구조의 페로브스카이트 층을 3차원(3-dimension, 3D) 페로브 스카이트 결정 표면에 형성함으로써 $3 \mathrm{D}-2 \mathrm{D}$ 복합 차원 의 페로브스카이트를 형성하여 고효율 소자를 구현하였 다. (Fig. 6-(c))일반적으로 페로브스카이트 표면에 형성 

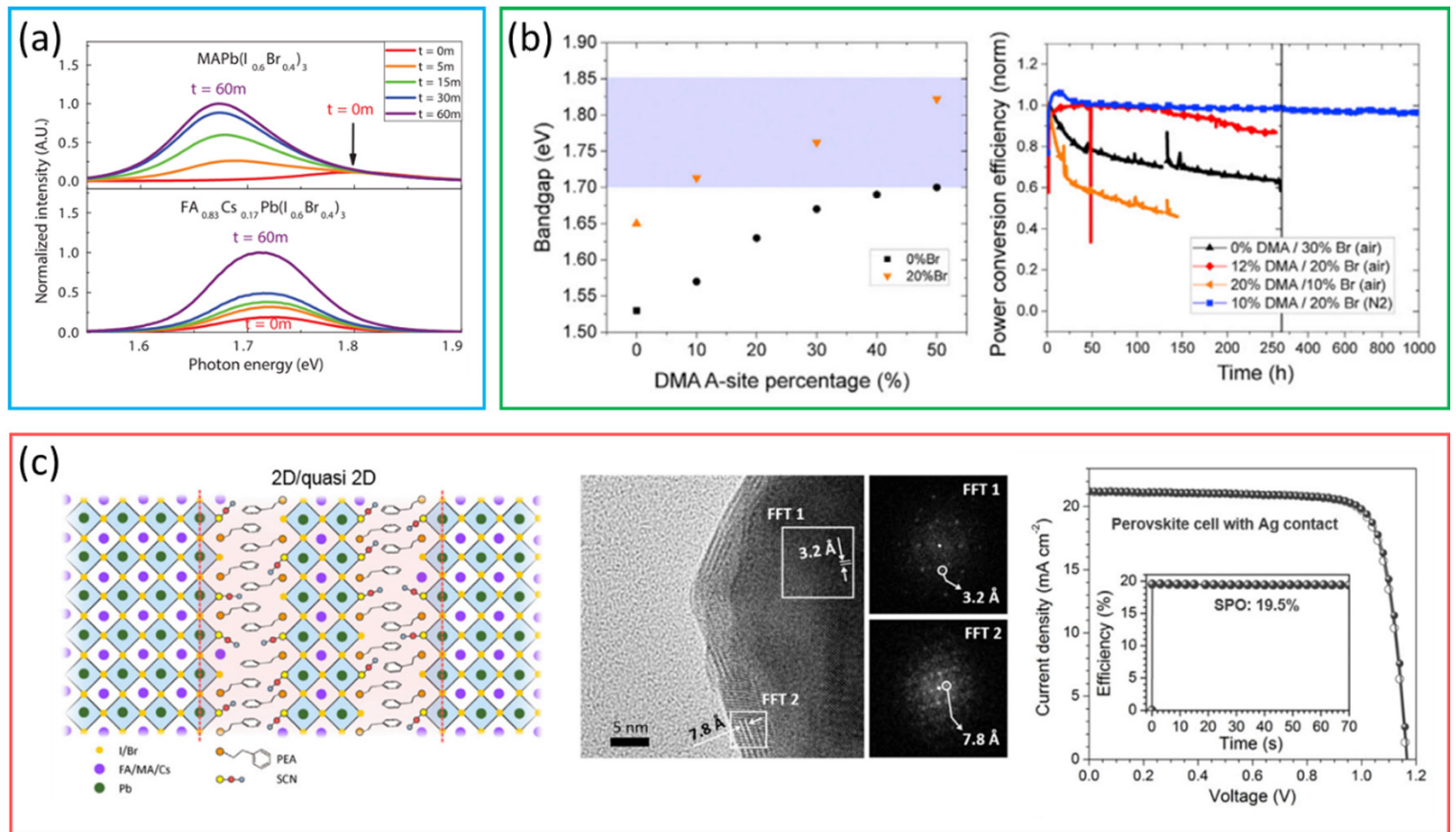

Fig. 6. 광안정성 및 고효율 상부 소자용 페로브스카이트 소자 합성을 위한 A site 양이온이 치환된 페로브스카이트. (a) Cs ${ }^{+}$이온을 A site에 포함한 $1.75 \mathrm{eV}$ 페로브스카이트 소자의 광 노출 시간에 따른 photoluminescence (PL) 변화, ${ }^{18)}$ (b) dimethylammonium (DMA) 치환을 통해 광 안정성 및 밴드갭 조절을 확보한 넓은 밴드갭의 페로브스카이트,11) (c) phenethylammonium (PEA)과 thiocyanate (SCN') 이온 을 기반으로 한 고효율 3D-2D 넓은 밴드갭의 페로브스카이트 소재의 구조 모식도 및 TEM, 그리고 소자 효율 특성.9)

된 2D 페로브스카이트 층은 긴 체인의 양이온 분자(이 연 구에서는 phenethylammonium $\left(\mathrm{PEA}^{+}\right)$이 사용됨)로 인하여 여기된 전자-정공의 이동이 방해를 받는데 해당 연구에서는 $2 \mathrm{D}$ 페로브스카이트 내의 할라이드 조성에 thiocyanate $\left(\mathrm{SCN}^{-}\right)$이온을 치환함으로써 전기적 특성 을 향상시켜 우수한 전기적 특성을 확보하는 동시에 $\mathrm{Br}$ 함량이 높아지면서 형성된 페로브스카이트 표면 결함을 passivation하여 전압 결핍을 줄이고 충진율(fill factor) 을 증가시켜 고효율 소자를 구현하였다. $\left.{ }^{9}\right)$

많은 연구진들의 노력으로 상부 소자용 넓은 밴드갭의 페로브스카이트는 빠르게 고효율을 확보할 수 있었다. 그 러나 대부분의 연구가 $1.67-1.73 \mathrm{eV}$ 밴드갭에 해당하는 연구로써 이는 실리콘이나 CIGS와는 이상적인 조합을 보이고 있으나 좁은 밴드갭의 페로브스카이트와는 적절 한 조합이 아니다. 따라서 앞으로는 $1.77-1.83 \mathrm{eV}$ 영역 의 더 넓은 밴드갭의 페로브스카이트에 대한 연구가 활발 히 이뤄져야 한다.

\section{2 실리콘 또는 CIGS 하부 소자를 위한 페로브 스카이트 상부 소자}

페로브스카이트 상부 소자는 전자 수송층(electron transport layer, ETL), 광흡수층, 정공 수송층(hole transport layer, HTL), 투명전극, 금속 전극으로 이루 어져 있는데, 2 터미널 적층형 태양전지의 경우 하부 소 자에 따라 가능한 상부 소자 공정 온도가 다르기 때문에 이를 반드시 고려해야 한다. 페로브스카이트 광흡수층은 대부분 100-150 도 사이의 공정 온도에서 제작되기 때문 에 하부 소자에 따른 공정 온도 제약이 거의 없다. 하지 만, 금속산화물 기반의 무기 전하 수송층 $\left(\mathrm{TiO}_{2}, \mathrm{SnO}_{2}\right.$, $\mathrm{NiO}$ 등)을 도입하기 위해 경우에 따라 300 도 이상의 고 온 후열처리 공정이 필요하므로 이종 접합 실리콘 태양전 지나 박막 태양전지, 페로브스카이트 하부 소자 등에 금 속산화물 전하 수송층을 적용하기에는 제약이 따른다. 따 라서, 200 도 이하의 저온 솔-겔 방법이나 산화물 나노 입자를 용매에 분산시켜 스핀 코팅하는 방법 등을 사용하 


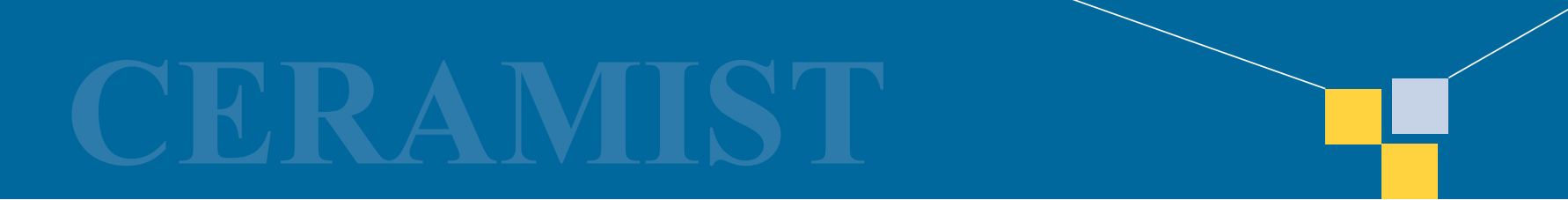

특 집 박익재, 김동회

여 무기 전하 수송층을 형성한다. ${ }^{19-21)}$ 반면 4 터미널 적 층형 태양전지 소자의 경우 상/하부 소자가 전기적으로 독립이기 때문에 이러한 전류 매칭이나 공정 온도와 같은 제한으로부터 상대적으로 자유롭다. 따라서 실리콘이나 CIGS, 페로브스카이트 등 주요 하부 소자에 따른 페로브 스카이트 기반 상부 소자의 주요 이슈 및 연구 동향에 대 해 보다 자세하게 논의하고자 한다.

기본적으로 고효율 적층형 태양전지 구현을 위한 페로 브스카이트 상부 연구 관점에서의 핵심 이슈는 크게 공정 온도 및 적합성, 매칭 광전류 극대화, 광전압 손실 최소 화로 분류할 수 있다. 4 터미널 구조의 적층형 소자에서 는 하부 소자과 별도의 기판 위에 상부 소자을 형성하기 때문에 공정 온도 및 적합성에 상대적으로 제약이 적은 대신 두 소자의 기계적인 연결 시의 빛 손실 최소화를 연 구가 필요하다. 이러한 관점에서 접근한다면, 실리콘과 CIGS 하부 소자 관점에서 페로브스카이트 상부 소자의 기술적 이슈는 거의 같다고 할 수 있다.

(a)

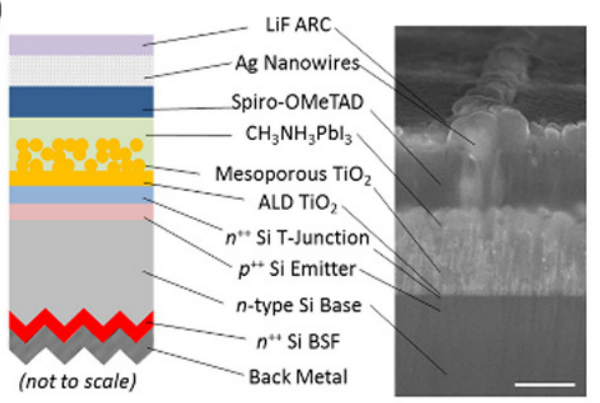

(b)

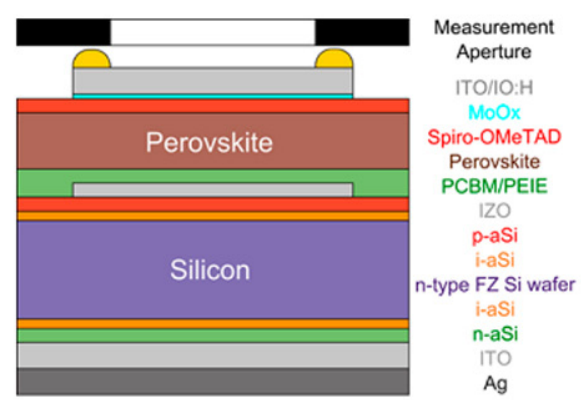

\subsection{1공정 온도 및 적합성}

동종 접합 (homo-junction) 타입의 실리콘 하부 소자 는 500 도 이상의 고온 공정이 가능하기 때문에 $\mathrm{TiO}_{2}$ mesoporous 층이 도입된 $\mathrm{n}-\mathrm{i}-\mathrm{p}$ 구조의 페로브스카이 트 상부 소자 적용이 가능하다. 미국 MIT 와 Stanford 대학의 공동 연구에 의해 최초로 보고된 페로브스카이 트-실리콘 탠덤 소자에서 back surface field (BSF) 타 입의 실리콘 하부 소자 위에 $\mathrm{n}-\mathrm{i}-\mathrm{p}$ 구조를 도입하여 $13.7 \%$ 광전 변환 효율의 소자를 보고하였다(Fig. 7-(a)). ${ }^{22)}$ 그러나 Fig. 7-(b)와 같이 우수한 효율의 적층 형 소자를 위해 동종 접합 실리콘 대비 우수한 이종 접합 (heterojunction with intrinsic thin film, HIT) 실리콘 하부 소자를 도입하는 방향의 적층형 태양전지 소자 연구 가 시작되었다. ${ }^{23,24)}$ 그러나 HIT 소자 내의 passivation 역할을 하는 amorphous $\mathrm{Si}$ 박막층이 200 도 이상의 온 도에서 열화되기 때문에 고온 공정이 불가능하다. 따라 서, 최근의 $\mathrm{HIT}$ 소자 기반 고효율 탠덤 소자에서는 저온 에서 전하 수송층을 형성할 수 있는 $\mathrm{p}-\mathrm{i}-\mathrm{n}$ 구조의 상부

(c)

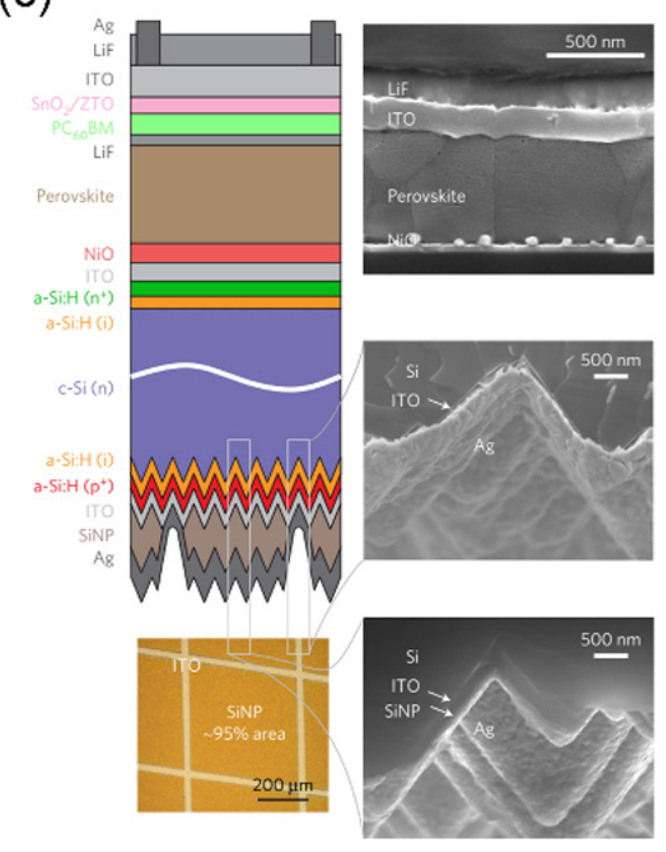

Fig. 7. 실리콘 하부 소자에 따른 페로브스카이트-실리콘 적층형 태양전지 모식도 및 SEM 이미지. (a) BSF 구조 실리콘, (b) 양면 폴리싱된 HIT 소자 (c) 후면 텍스쳐 구조가 적용된 HIT 소자로 제작된 페로브스카이트-실리콘 적층형 태양전지 소자19,22,23) 
(a)

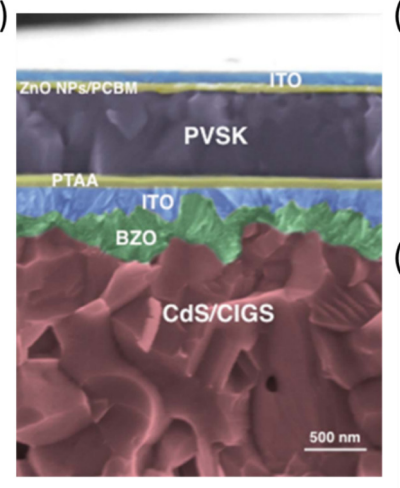

(b)

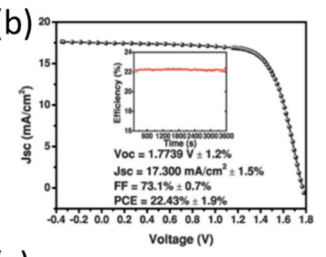

(c)

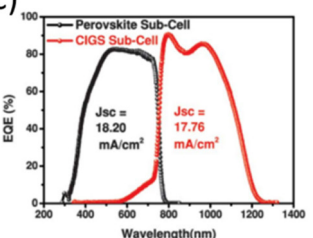

Fig. 8. 2 터미널 페로브스카이트-CIGS 적층형 태양전지의 (a) 구 조 및 (b) 전류-전압 특성 $(J-V)$ 과 (c) 파장에 따른 양자효 율 $(\mathrm{EQE})^{8)}$

소자가 널리 적용되고 있다. 2017년 Stanford 대학의 McGehee 교수팀에서 HIT 실리콘 하부 소자 위에 nickel nitrate hexahydrate 용액을 이용하여 190 도에서 열처 리를 통해 $\mathrm{NiO}_{\mathrm{x}}$ 정공 수송층을 형성하고 $\mathrm{PC}_{60} \mathrm{BM} / \mathrm{SnO}_{2} /$ ZTO (zinc tin oxide) 전자 수송층을 각각 열기상증착법 (thermal evaporation), Pulsed-CVD 공정으로 증착하 여 $23.6 \%$ 효율의 페로브스카이트-실리콘 적층형 태양전 지를 보고하였다(Fig. 7-(c)). ${ }^{19}$

고효율의 페로브스카이트 상부 소자는 대부분의 경우 용액 공정을 기반으로 한다. 최적화된 페로브스카이트 광 흡수층의 두께는 400-500 나노미터 수준으로 알려져 있 다. 때문에 페로브스카이트 층을 형성할 하부 소자의 표 면 거칠기를 최소화시켜야 수 백 나노미터 두께의 균일한 페로브스카이트 광흡수층의 형성이 가능하다. 따라서 실 리콘 태양전지의 경우, 일반적으로 사용하는 양쪽 면에 텍스쳐가 있는 실리콘 태양전지가 아닌, 한 쪽 면이 평평 하게 폴리싱 된 웨이퍼를 사용한다. 그러나 CIGS 하부 소자의 경우 수백 나노 수준의 표면 거칠기가 CIGS 결정 성장 과정에서 형성되기 때문에 용액 공정을 통해서 높은 균일도를 지닌 페로브스카이트 광흡수층을 형성하는데 어려움이 있었다. 이로 인하여 고효율의 2 터미널 페로브 스카이트-CIGS 적층형 태양전지 소자 구현에 한계가 있 었다. 2018년 미국 UCLA의 Yang 교수팀은 스퍼터를 이 용해 boron-doped ZnO (BZO) 및 indium tin oxide
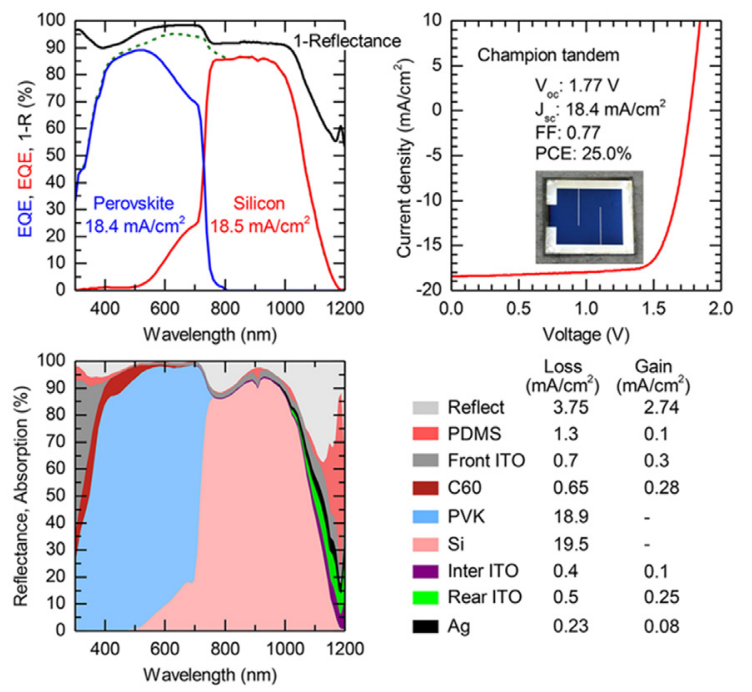

Fig. 9. PMDS가 적용된 페로브스카이트-실리콘 적층형 태양전지 소자의 $E Q E$ 및 $J-V$ 곡선 25)

(ITO)를 형성한 뒤 화학적, 기계적 폴리싱을 통해 표면 거칠기를 최소화한 뒤 페로브스카이트 상부 소자를 형성 하는 기술을 통해 $22.4 \%$ 효율의 2 터미널 페로브스카이 트-CIGS 소자을 제작하였다. (Fig. 8) ${ }^{8)}$

\subsection{2 매칭 광전류 극대화}

적층형 태양전지 소자의 매칭 광전류를 극대화하기 위 해서는 광포집을 극대화한 후 상하부 하위 소자의 광전류 를 정확하게 매칭시켜야 한다. 전자를 위해 상부 소자의 전하 수송층 및 투명 전극에서의 기생 흡수 및 반사도 (reflectance)를 최소화해야 하고, 후자를 위해서는 페로 브스카이트 광흡수층의 두께를 조절하여 상부 소자에서 흡수되는 빛의 양을 조절하거나 밴드갭을 조절하여 흡수 할 수 있는 파장을 조절해야 한다. 2018년 미국 University of Colorado의 McGehee 교수팀은 피라미 드 구조의 polydimethylsiloxane (PDMS)을 상부 소자 에 도입하여 입사광의 기생 흡수 및 반사를 최소화하였 다. 또한, 페로브스카이트의 밴드갭을 조절해 상부 소자 와 하부 소자 간의 광전류 밀도를 완벽하게 매칭시켜 $25.0 \%$ 효율의 적층형 소자를 제작하였다(Fig. 9). ${ }^{25)}$

광포집을 극대화하기 위한 또 하나의 중요한 이슈는 양 면 텍스쳐 구조의 실리콘 하부 소자 도입이다. 양면 텍스 


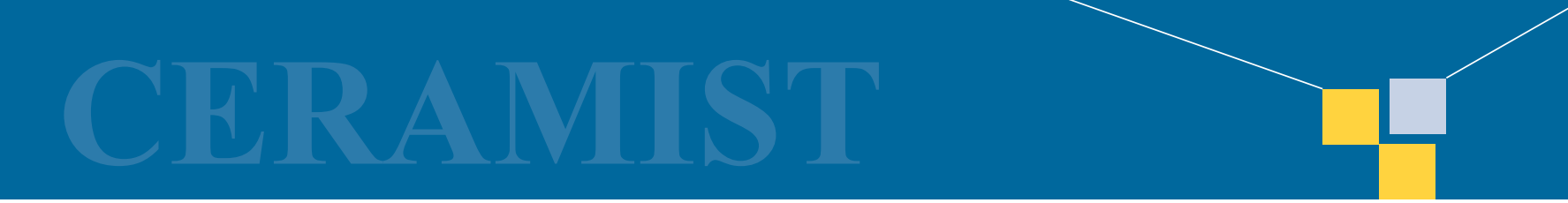

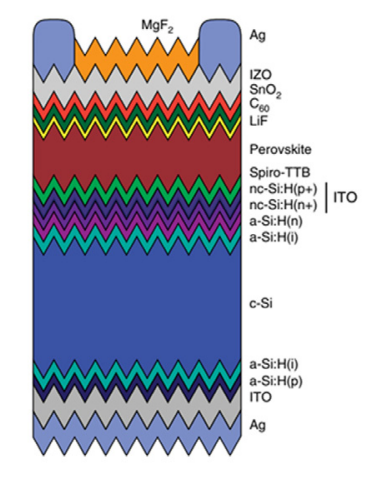
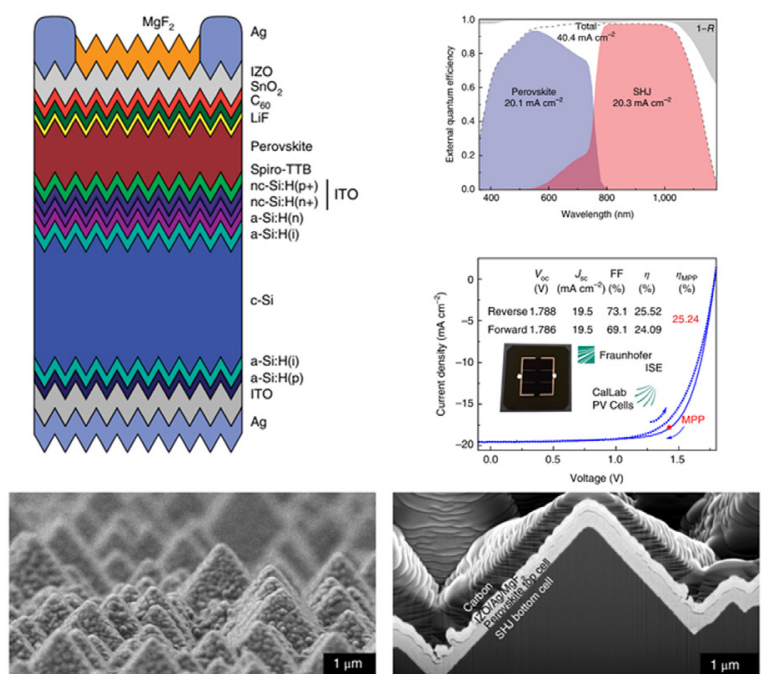

Fig. 10. 열기상증착법을 통해 텍스쳐 구조의 실리콘 하부 소자 위 에 형성된 페로브스카이트 상부 소자 및 $J-V, E Q E$ 곡선기

쳐 구조는 실리콘 표면을 수 마이크론 단위로 에칭하여 소자 계면에서 입사광의 반사도를 최소화하고 빛의 이동 경로를 늘려 장파장 영역의 광전류 밀도를 향상시킬 수 있는 중요한 기술이다. 그러나 스핀 코팅을 이용한 용액 공정으로는 수 마이크론 단위의 단차를 갖는 실리콘 하부 소자 위에 균일한 수백 나노미터 두께의 페로브스카이트 박막을 형성하기 힘들다. 최근, 스위스 Écolepolytechnique fédérale de Lausanne (EPFL)의 Ballif 교수팀은 열기상증 착법을 이용하여 양면 텍스쳐 구조의 실리콘 하부 소자에 $\mathrm{PbI}_{2}$ 및 $\mathrm{CsBr}$ 을 동시에 증착한 후 $\mathrm{FABr}$ 및 $\mathrm{FAI}$ 용액을 박막 위에 스핀 코팅하여 페로브스카이트를 형성하는 기 술을 보고하였다. 이를 통해 텍스쳐 표면을 따라 균일한 페로브스카이트 박막을 형성하였고 $19.5 \mathrm{~mA} / \mathrm{cm}^{2}$ 의 높 은 광전류 밀도를 갖는 인증 효율 $25.2 \%$ 의 페로브스카이 트-실리콘 적층형 소자를 구현하였다. (Fig. 10)ㄱ)

\subsection{3 광전압 손실 최소화}

페로브스카이트의 결함 제어 기술은 소자의 광전압 손 실 및 이력 현상(hysteresis) 등을 줄일 수 있는 중요한 기술이다. 더욱이 페로브스카이트의 밴드갭이 증가할 수 록 광전압 손실이 커지기 때문에 결함 제어는 고효율 적 층형 태양전지 소자를 위한 중요한 이슈이다. 탠덤 소자 의 광전압은 각 하위 소자의 광전압의 합이기 때문에 상 부 소자의 광전압 향상은 적층형 소자의 광전압 향상으로 나타난다. 따라서, 단일 접합에서와 마찬가지로 상부 소 자의 광흡수층을 개선하는 연구가 이루어졌다. 최근 미국 Nebraska-Lincoln 대학의 Huang 교수팀은 $\mathrm{MACl}$ 및 $\mathrm{MAH}_{2} \mathrm{PO}_{2}$ 를 페로브스카이트 전구체에 첨가하여 광전압 손실을 최소화하는 연구를 진행하였다. ${ }^{26)} \mathrm{Fig} .11$ 와 같이
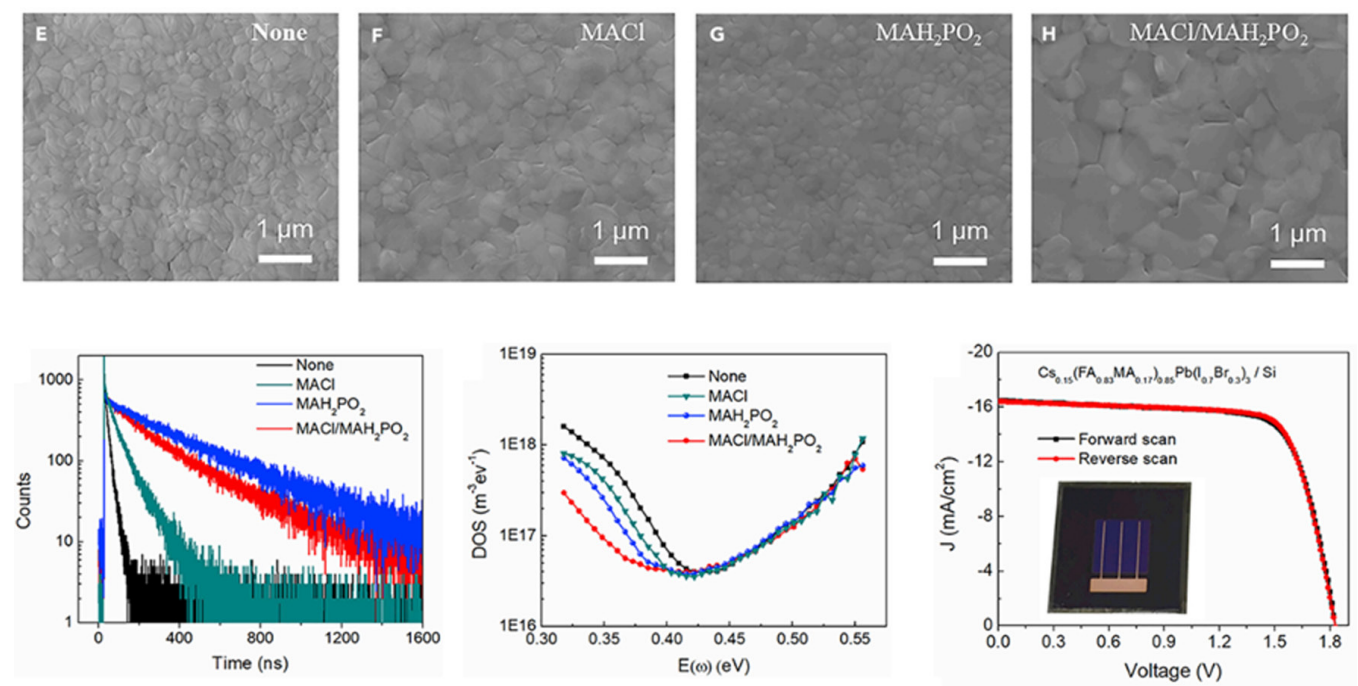

Fig. 11. $\mathrm{MACl}$ 및 $\mathrm{MAH}_{2} \mathrm{PO}_{2}$ 첨가제를 통한 페로브스카이트 이미지, 결함 농도 및 $J-V$ 곡선26) 
$\mathrm{MACl}$ 첨가제는 페로브스카이트의 결정 크기를 증가시켜 결정립계(grain boundary) 밀도가 감소하였고, $\mathrm{MAH}_{2} \mathrm{PO}_{2}$ 첨가제는 결정립계의 결함을 passivation 하 여 비발광 전자-정공 재결합을 감소시켰다. 개선된 페로 브스카이트 상부 소자을 $\mathrm{HIT}$ 소자에 적용하여 $1.80 \mathrm{~V}$ 의 높은 광전압을 달성하였다. 한편, 오스트레일리아 The Australian National University의 Catchpole 교수팀 은 4 터미널 상부 소자에서, $\mathrm{Cs} / \mathrm{FA} / \mathrm{MA}$ triple 양이온이 포함된 페로브스카이트 광흡수층에 $\mathrm{Rb}^{+}$양이온을 첨가 하여 페로브스카이트의 결정성을 향상시키고 결정립계 에서의 결함의 이동을 억제하였다. ${ }^{15)}$ 이로 인해 $1.73 \mathrm{eV}$ 의 밴드갭에서 이력현상이 크게 감소하였고, 100 시간 동 안의 12 시간 간격 on-off 구동 후 처음 효율의 $95 \%$ 를 유지하는 구동 안정성을 보였다. 이를 Interdigitated back contact (IBC) 소자에 적층하여 $26.4 \%$ 의 효율을 달 성하였다.

\section{4. 하부 소자를 위한 좁은 밴드갭의 유무기 폐로브 스카이트}

\section{1 좁은 밴드갭 $\mathrm{Pb}-\mathrm{Sn}$ 페로브스카이트}

$\mathrm{ABX}_{3}$ 의 결정 구조를 지니고 있는 페로브스카이트는 각 $\mathrm{A}, \mathrm{B}, \mathrm{X}$ 위치의 조성에 따라서 밴드갭을 $1.2-2.3 \mathrm{eV}$ 까지 조절할 수 있고 따라서 페로스카이트-페로브스카 이트 적층형 태양전지로의 구현을 위하여 의미 있는 연구 들이 진행되어 왔다. 특히, 페로스카이트-페로브스카이 트 적층형 태양전지는 앞서 설명한 실리콘 혹은 CIGS를 이용한 이종 접합 적층형 태양전지와 비교했을 때 유사한 (a)

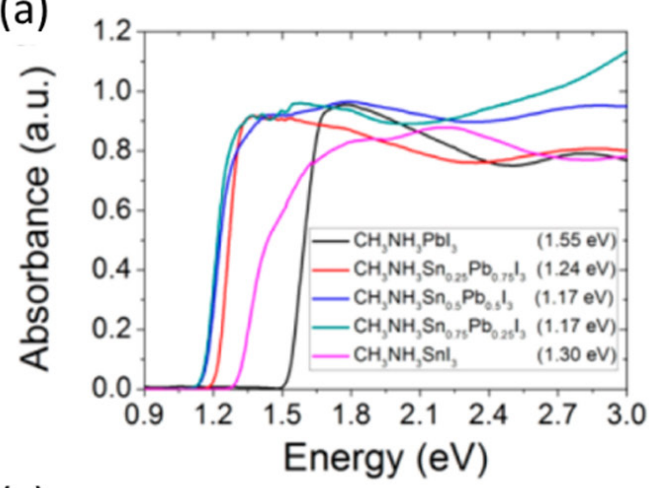

(c)

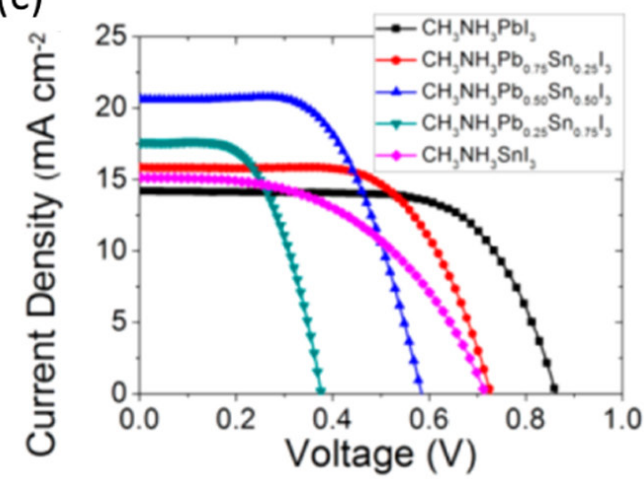

(b)

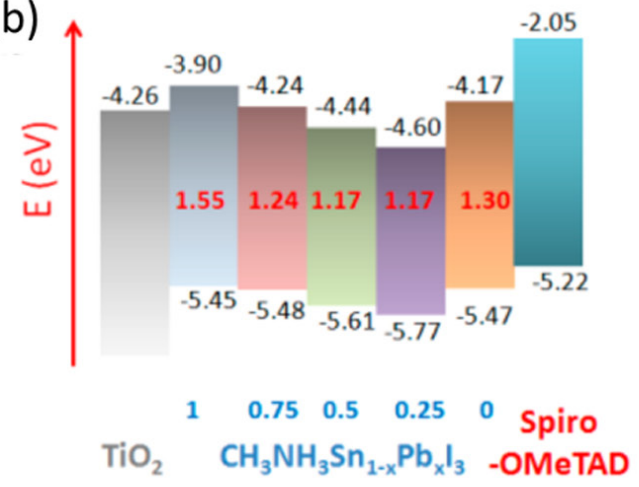

(d)

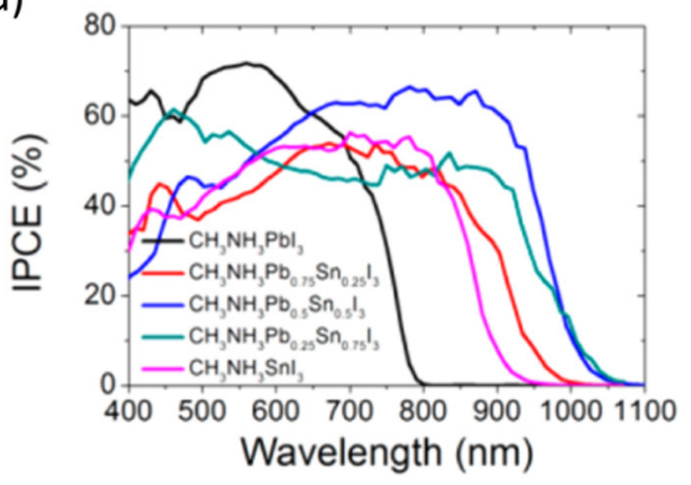

Fig. 12. $\mathrm{Pb}-\mathrm{Sn}$ alloy 기반의 페로브스카이트 소재의 흡광 및 단일 태양전지 소자 특성. (a) $\mathrm{Pb}-\mathrm{Sn}$ 비율에 따른 흡광도, (b)이에 따른 밴드갭 및 밴드 위치의 변화, (c) Pb-Sn 페로브스카이트를 이용한 태양전지의 광전 변환 특성 $(J-V)$ 및 (d) 파장에 따른 광변환 효율 (EQE) $)^{27)}$ 
이론 효율값을 지니고 있으면서 동시에 저온 솔루션 공정 및 저렴한 생산 원가로 인하여 저비용, 고효율 태양전지 소자에 대한 높은 가능성과 동시에 초경량 유연 소자의 가능성까지 두루 갖추고 있다. 현재까지 페로브스카이트 태양전지는 $\mathrm{FA} / \mathrm{MA} / \mathrm{Cs}$ triple 양이온과 $\mathrm{I}-\mathrm{Br}$ 비율이 100:0부터 85:15 사이의 alloy 형태의 조성을 가진 1.50-1.63 eV 범위의 단일접합 소자를 기반으로 이뤄졌 다. 특히, $\mathrm{A}$ 와 X 위치의 조성을 조절함으로써 밴드갭의 변화 및 결정 구조 및 결함 특성, 이온 분리 특성 등 페로 브스카이트의 다양한 특성들이 보고 되었다. 이러한 연구 들은 $\mathrm{B}$ 위치에 $\mathrm{Pb}$ 만을 사용한다는 공통점을 지니고 있 다. 2014년 Northwestern 대학의 Kanatzidis 교수 연 구팀은 $\mathrm{B}$ 위치의 $\mathrm{Pb}^{2+}$ 를 $\mathrm{Sn}^{2+}$ 로 치환하게 될 경우 독특 한 밴드갭 변화가 발생한다는 것을 보고하였다. ${ }^{27)} \mathrm{Fig}$. 12 에 나타난 것과 같이 $\mathrm{A}$ 와 $\mathrm{X}$ 위치의 조성을 $\mathrm{MA}$ 와 iodide로 유지한 채 $\mathrm{Pb}-\mathrm{Sn}$ alloy를 형성할 경우, 이전에 $\mathrm{A}$ 또는 $\mathrm{X}$ 위치의 조성을 바꿀 때 밴드갭이 한 방향으로 변하는 것과 다르게 밴드갭이 $1.55 \mathrm{eV}$ 에서 감소하기 시 작하여 $\mathrm{Pb}-\mathrm{Sn}$ 비율이 $0.50: 0.50$ 부터 $0.25: 0.75$ 범 위에 이를 때, $1.17 \mathrm{eV}$ 까지 감소하고 $\mathrm{Pb}$ 를 $\mathrm{Sn}$ 으로 전부 치환한 경우 $1.30 \mathrm{eV}$ 까지 다시 증가하는 밴드갭 보잉 (Bandgap bowing) 현상을 확인할 수 있다. 이러한 경향 은 $\mathrm{Pb}-\mathrm{Sn}$ alloy 형성 시, $\mathrm{Pb}$ 와 $\mathrm{Sn}$ 원소의 $\mathrm{p}$-orbital에 의해 발생하는 spin-orbit coupling 효과와 $\mathrm{Pb}-\mathrm{Sn}$ alloy 비율에 따라서 페로브스카이트 결정 구조의 왜곡으 로 인해 발생하는 밴드갭 변화가 상충되면서 발생하는 효 과로 알려져 있다. ${ }^{28)}$ 이는 $1.48-1.50 \mathrm{eV}$ 정도의 가장 좁 은 밴드갭을 가지는 $\mathrm{Pb}$ 기반의 페로브스카이트가 $\mathrm{Sn}$ 치 환을 통하여 밴드갭을 더욱 좁힘으로써 실리콘이나 $\mathrm{CIGS}$ 와 같이 적층형 태양전지의 하부 소자로의 적용 가 능성을 보인 것이다. 그러나 $\mathrm{Sn}^{2+}$ 기반의 소재는 $\mathrm{Sn}^{4+}$ 로 산화하려는 특성이 매우 강하기 때문에, 공기와 수분 등 환경에 매우 민감하고 제작된 박막 역시 안정성 측면에서 매우 취약하다. Nripan 교수팀은 $1.41 \mathrm{eV}$ 의 $\mathrm{FASnI}_{3}$ 페 로브스카이트 형성 시, 전구체 용액에 $\mathrm{SnF}_{2}$ 첨가함으로 써 $\mathrm{Sn}^{2+}$ 가 $\mathrm{Sn}^{4+}$ 로 산화되는 것을 막아 $2.1 \%$ 의 무연 $(\mathrm{Pb}-$ free) 페로브스카이트 태양전지를 보고하였다. ${ }^{29)}$ 이후 한
국화학연구원의 석상일 박사 연구팀은 동일 조성에서 $\mathrm{SnF}_{2}$ 와 pyrazine 조합을 통하여 보다 효과적으로 산화 를 억제함으로써 $2 \%$ 의 효율을 $4.8 \%$ 까지 향상시켰다. ${ }^{30}$ 이와 같이 환원제를 통하여 $\mathrm{Sn}^{2+}$ 의 산화를 제어함으로써 $\mathrm{Pb}-\mathrm{Sn}$ 기반의 좁은 밴드갭 페로브스카이트 연구가 점진 적으로 진행되었고, 이에 대해 아래에서 자세하게 소개를 하고자 한다.

\section{2 고효율 하부 소자를 위한 좁은 밴드갭 $\mathrm{Pb}-\mathrm{Sn}$ 페로브스카이트의 특성 개선}

\subsubsection{A-site alloy를 이용한 좁은 밴드갭 $\mathrm{Pb}-\mathrm{Sn}$ 페로브 스카이트}

이후 연구들을 살펴보면, 환원제를 첨가하는 방법에서 나아가서 보다 좁은 밴드갭과 안정성을 확보하기 위하여 $\mathrm{Pb}-\mathrm{Sn}$ alloy 형성 시 발생하는 밴드갭 보잉 효과를 적극 적으로 활용하게 된다. 또한 기존 $\mathrm{Pb}-\mathrm{Sn}$ 페로브스카이 트 태양전지를 형성할 때에는 n-i-p 구조를 사용하였는 데, 이 때 정공 수송층에 도펀트로 사용되는 물질에 포함 된 lithium 또는 cobalt가 페로브스카이트 내의 $\mathrm{Sn}$ 과 반 응하여 페로브스카이트 소재 안정성에 영향을 끼칠 수 있 다는 보고를 바탕으로 $\mathrm{p}-\mathrm{i}-\mathrm{n}$ 구조 기반의 소자 형태가 연구되기 시작하였다. ${ }^{31)}$ 영국 Oxford 대학의 Snaith 교 수 연구팀은 $1.25 \mathrm{eV}$ 의 밴드갭을 가진 $\mathrm{Pb}_{0.5}-\mathrm{Sn}_{0.5}$ 페로 브스카이트 소자의 $\mathrm{A}$-site를 순수한 $\mathrm{FA}$ 에서 $\mathrm{FA}_{0.75}$ $\mathrm{CS}_{0.25}$ alloy로 구성함으로써 페로브스카이트의 구조 안 정성을 확보하고 균일한 막을 형성함으로써 $10.9 \%$ 의 효 율을 $14.8 \%$ 로 향상시켰다. (Fig. 13-(a)) $)^{10)}$ 나아가 1.8 $\mathrm{eV}$ 페로브스카이트 조성과 2 터미널 페로브스카이트-페 로브스카이트 태양전지를 구현하여 $20.3 \%$ 의 효율을 달 성한다. (Fig. 13-(b))에 소개된 것과 같이 미국 Toledo 대학의 Yan 교수 연구팀은 위 연구와 비슷한 시기에 $\mathrm{FASnI}$ 와 $\mathrm{MAPbI}_{3}$ 전구체 용액을 각각 만들어서 섞는 방 법을 이용하여 $\mathrm{FA}_{0.6} \mathrm{MA}_{0.4} \mathrm{Sn}_{0.6} \mathrm{~Pb}_{0.4} \mathrm{I}_{3}$ 페로브스카이트를 형성하였을 때 밴드갭 보잉 현상이 가장 심화되어 가장 좁은 밴드갭을 지님과 동시에 높은 균일도의 박막이 형성 됨을 발견하고 이 소자로 적용하여 $15.0 \%$ 의 효율을 기록 

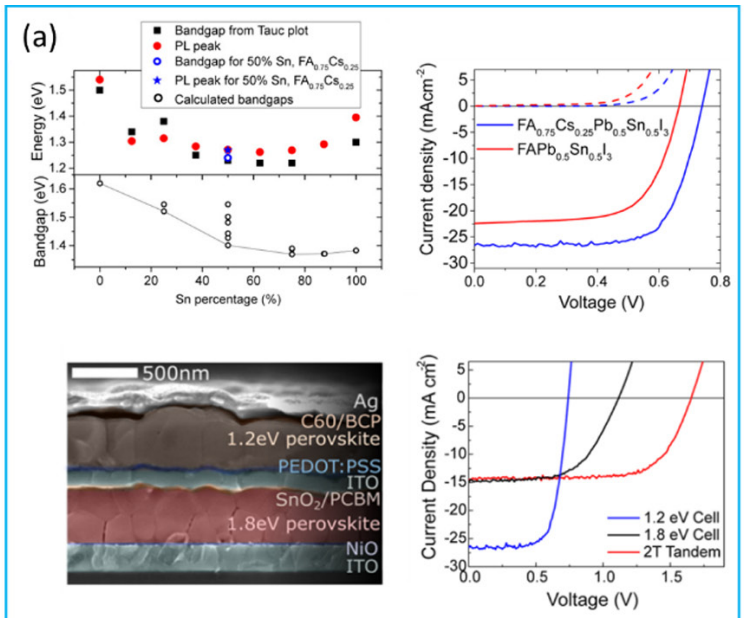

(b)
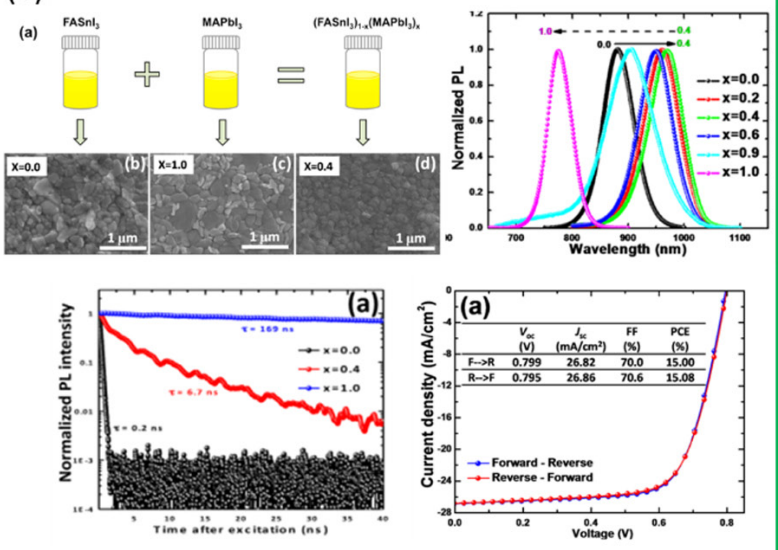

Fig. 13. A-site alloying을 통한 고효율 Pb-Sn 페로브스카이트 태양전지 형성 및 특성. (a) FA-Cs alloying을 이용하여 형성한 $1.25 \mathrm{eV}$ 의 $\mathrm{Pb}_{0.5}-\mathrm{Sn}_{0.5}$ 페로브스카이트 태양전지의 소자 특성 및 이를 이용한 페로브스카이트-페로브스카이트 2 터미널 태양전지, ${ }^{10)}(\mathrm{b}) \mathrm{FA}-\mathrm{MA}$ alloying을 이용하여 형성된 $\mathrm{Pb}-\mathrm{Sn}$ 페로브스카이트의 $\mathrm{PL}$ 특성 및 표면 특성 31$)$

한다. ${ }^{31)}$ 그러나 A-site alloying을 통하여 안정화시켰음 에도 불구하고 time-resolved photoluminescence (TRPL) 분석 결과에 따른 전하 수명은 $10 \mathrm{~ns}$ 이하로, 이 는 광흡수층에서 생성된 전자-정공이 매우 빠른 속도로 재결합된다는 것을 확인할 수 있었다. 결과적으로 A-site alloying을 통하여 형성된 $\mathrm{Pb}-\mathrm{Sn}$ 페로브스카이 트 박막의 내적 특성이 향상되었으나 기존 $\mathrm{Pb}$ 기반의 페 로브스카이트 대비 전하 이동 특성이 100 배 이상 악화됨 을 확인하였다. 이후, 2017년에는 Stanford 대학의 $\mathrm{McGehee}$ 교수 연구팀은 $\mathrm{Cs}^{+}$양이온이 $\mathrm{Pb}-\mathrm{Sn}$ 페로브스 카이트 내에서 $\mathrm{FA}^{+}$와 alloy를 형성했을 때 $\mathrm{PbI}_{6}$ octahedra에 영향을 끼치지만 $\mathrm{SnI}_{6}$ 에는 octahedral tilting이 발생하지 않고 단순히 격자 길이에만 영향을 준 다는 결정학적 결과를 바탕으로 하여 FA-Cs alloying이 $\mathrm{Pb}-\mathrm{Sn}$ 페로브스카이트 밴드갭에 미치는 영향과 이를 바 탕으로 전하수집층과의 최적의 조합을 찾음으로써, $17.8 \%$ 의 고효율 소자를 구현하였다. ${ }^{32)}$ 그러나, alloying 을 통하여 고품질의 박막을 형성하고, 밴드갭에 미치는 영향을 확인하였으나 $\mathrm{Pb}-\mathrm{Sn}$ 페로브스카이트의 전기적 특성이 개선되지는 않았다. 좁은 밴드갭 $\mathrm{Pb}-\mathrm{Sn}$ 페로브 스카이트의 전기적 특성을 향상시키는 연구에 대해서는 이후에 자세하게 설명하고자 한다.

\subsection{2고효율의 낮은 밴드갭 $\mathrm{Pb}-\mathrm{Sn}$ 페로브스카이트를 위한 첨가제 공정법}

페로브스카이트 박막의 전하 수명이나 전하 이동도 등 은 소재 내부의 결함과 밀접한 관련이 있는 걸로 알려져 있다. 이러한 결함을 해결하기 위해서 일반적으로 결정의 크기를 키워서 결정립계의 밀도를 감소하거나, 결함을 회 복시켜줄 수 있는 음이온을 추가하거나 결정립계의 표면 (surface)이나 박막의 노출면을 passivation 하는 방법 등이 주로 사용되었다. $\mathrm{Pb}-\mathrm{Sn}$ 페로브스카이트의 경우, $\mathrm{Sn}^{2+}$ 의 산화를 고려하면서 동시에 결함을 해결할 수 있는 첨가제에 대한 연구가 상대적으로 덜 이루어졌었고 이에 대한 연구가 최근에 활발히 진행되고 있다. 이 분야에 대 해서는 Toledo 대학의 Yan 교수 연구팀이 리딩을 하고 있는 것으로 알려져 있다.

일반적으로 $\mathrm{Sn}^{2+}$ 가 포함되면서 광흡수 특성이 현저하 게 떨어지기 때문에 장파장 대역에서 충분한 광흡수 특성 을 확보하기 위해서는 기존 $\mathrm{Pb}$ 페로브스카이트에서 최적 으로 알려진 500-600 nm의 두께보다 두꺼운 약 $1 \mu \mathrm{m}$ 에 달하는 두께의 페로브스카이트 층을 형성해야 한다. 기존의 방법을 바탕으로 이를 진행하게 되면, 기판에 수 직한 방향으로 많은 결정립계 결함이 존재하게 되어 낮은 전기적 특성을 지닌 $\mathrm{Pb}-\mathrm{Sn}$ 페로브스카이트 광흡수층에 


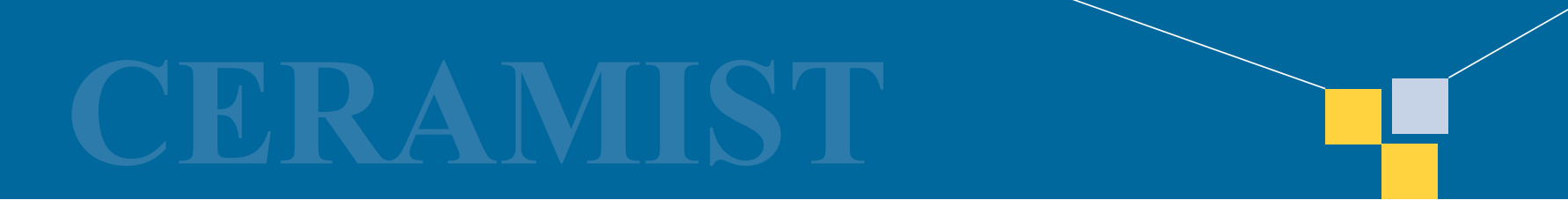

특 집 ㅁㅁ 박익재, 김동회

서 효율적인 전하-정공 분리를 방해하게 된다. Yan 교수 연구팀은 lead thiocyanate $\left(\mathrm{Pb}(\mathrm{SCN})_{2}\right)$ 를 전구체 용액 에 첨가하여 $\mathrm{Pb}-\mathrm{Sn}$ 페로브스카이트의 결정 크기를 수백 나노에서 수 마이크로 크기까지 증가시켰고, 기판과 수직 한 방향으로는 거의 단결정 형태로 결정립계가 존재하지 않도록 페로브스카이트를 형성하였다. ${ }^{33)}$ 그 결과가 Fig. 14-(a)에 잘 나타나있다. TRPL을 통하여 관찰한 페로브 스카이트 막의 전기적 전하수명 특성은 $620 \mathrm{~nm}$ 미터의 두께에서 기존의 수 $\mathrm{ns}$ 에서 $255 \mathrm{~ns}$ 까지 증가함을 확인하 였고, 이를 통하여 $17.5 \%$ 의 소자 효율을 달성했다. 그러 나 이는 빛을 충분히 흡수하는데 요구되는 $1 \mu \mathrm{m}$ 에는 부 족한 수치로, Fig. 14-(b)와 같이 추가적으로 chlorine을 이용한 bulk passivation을 통하여 결정성 향상, 전하이 동도 향상, electronic disorder 감소, trap-assisted recombination를 감소시켜 최적의 광전 변환 효율을 내 는 두께를 $750 \mathrm{~nm}$ 까지 향상시킨다. ${ }^{34)}$ 그 결과 기존에 보 고했던 $17.5 \%$ 를 $18.1 \%$ 까지 향상시킨다. 그리고 이를 2 터미널 페로브스카이트-페로브스카이트 소자에 적용하
여 21.0\%의 효율을 구현하였다. 한편, McGehee 교수 연 구팀은 formic acid를 첨가하고 동시에 $\mathrm{MACl}$ 을 기화시 켜서 형성된 $\mathrm{Pb}-\mathrm{Sn}$ 페로브스카이트 박막의 표면을 passivation 처리를 통해 소자의 표면 결함을 감소시켜 효율과 구동 안정성을 향상시켰다. ${ }^{35)}$

가장 최근에는 미국 NREL의 Kai 박사팀과 Toledo 대 학의 $\mathrm{Yan}$ 교수팀은 공동연구팀을 구성하여 $\mathrm{Pb}-\mathrm{Sn}$ 페로 브스카이트의 결정 표면에 guanidinium thiocyanate (GuaSCN)을 기반으로 한 새로운 2D 페로브스카이트 층 을 형성하여 결정립의 표면을 passivation 함으로써 전 하 수명 특성을 10 배 이상 $(1232 \mathrm{~ns})$ 향상시켰다. 이는 표 면 재결합 속도를 현저히 떨어뜨리는 결과를 가져왔고 그 결과 전하 확산 거리가 $0.53 \mu \mathrm{m}$ 에서 $2.5 \mu \mathrm{m}$ 까지 증가하 였다. (Fig. 14-(c) $)^{12)}$ 이를 바탕으로 최적의 광전 특성을 보이는 페로브스카이트 박막의 두께를 $1 \mu \mathrm{m}$ 이상까지 향 상시켜 높은 광전류 밀도 및 개방 전압을 확보할 수 있었 다. 그 결과 $1.25 \mathrm{eV}$ 밴드갭 $\mathrm{Pb}-\mathrm{Sn}$ 페로브스카이트를 기반으로 한 단일 접합 소자로 $20.2 \%$ 의 효율을 구현한

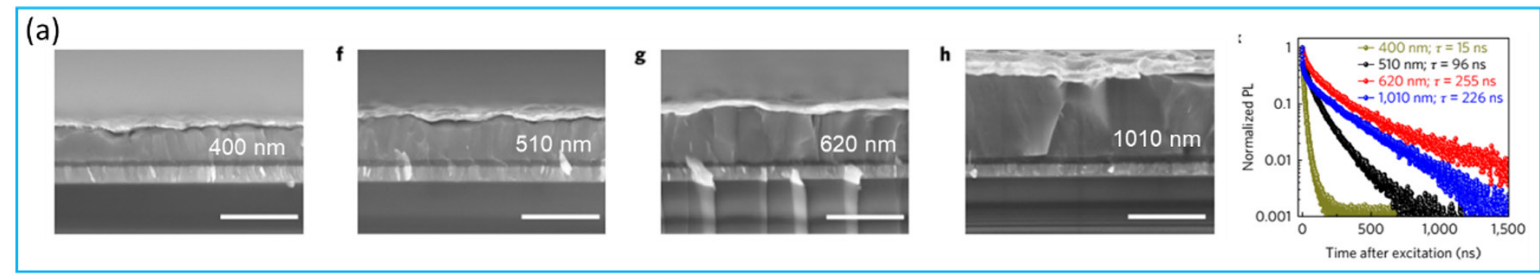

(b)
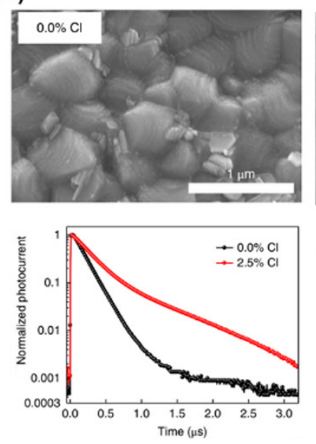
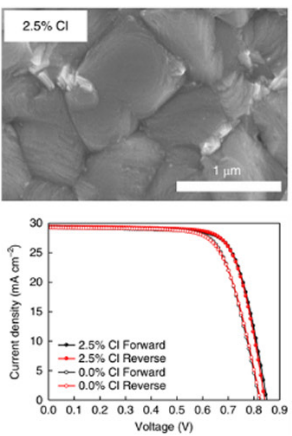

(c)
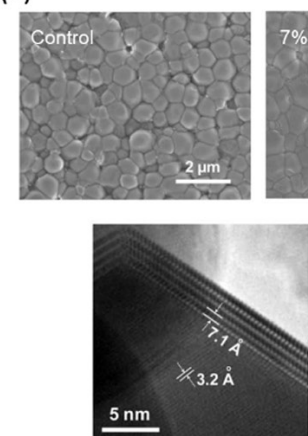

Fig. 14. 첨가제 공정을 통하여 전기적 특성이 향상된 $\mathrm{Pb}-\mathrm{Sn}$ 페로브스카이트. (a) Lead thiocyanate $\left(\mathrm{Pb}(\mathrm{SCN})_{2}\right)$ 첨가제를 이용하여 형성한 $\mathrm{Pb}_{0.4}-\mathrm{Sn}_{0.6}$ 페로브스카이트의 두께 및 두께에 따른 TRPL 특성, ${ }^{33)}(\mathrm{b})$ Chlorine 첨가제를 통하여 전기적 특성이 개선된 $\mathrm{Pb}_{0.4}-\mathrm{Sn}_{0.6}$ 페 로브스카이트의 표면 특성과 소자 특성,34) (c) Guanidinium thiocyanate (GuaSCN) 첨가제를 이용하여 GuaSCN 기반의 2D 층으로 표면을 passivaition한 $\mathrm{Pb}_{0.4}-\mathrm{Sn}_{0.6}$ 페로브스카이트의 표면 특성과 전기적 특성. 그리고 이를 기반으로 제작한 2 터미널 페로브스카 이트-페로브스카이트 적층형 태양전지의 전압-전류 특성 $(J-V)^{12)}$ 
것으로 $\mathrm{Sn}$ 기반으로는 처음으로 $20 \%$ 효율을 넘는 결과 를 보고하였다. 나아가 이를 2 터미널 페로브스카이트페로브스카이트 적층형 소자에 적용함으로써 $23.1 \%$ 의 효율을 달성하여 고효율 페로브스카이트-페로브스카이 트 소자의 가능성을 확인하였다. 그러나 이러한 효율 향 상에도 불구하고 아직까지 $\mathrm{Pb}-\mathrm{Sn}$ 페로브스카이트가 지 닌 낮은 안정성 및 밴드갭 대비 낮은 전류 밀도에 대한 연 구는 여전히 해결해야 할 문제이다.

\section{3 좁은 밴드갭의 $\mathrm{Pb}-\mathrm{Sn}$ 페로브스카이트의 안정성 및 내부 결함 연구}

좁은 밴드갭을 지닌 $\mathrm{Pb}-\mathrm{Sn}$ 페로브스카이트 기반의 연 구는 $\mathrm{Sn}^{2+}$ 산화나 박막 형성의 어려움, 낮은 광전 변환 효 율 등의 어려움으로 기존 $\mathrm{Pb}$ 페로브스카이트 연구 대비 상대적으로 적은 관심을 받았다. 2017년 이후 위에서 언 급한 우수한 연구 결과들을 기반으로 소자 제작 및 효율 부분에 있어서 많은 발전을 보였고, 이에 $\mathrm{Pb}-\mathrm{Sn}$ 페로브 스카이트 관련 연구에 대한 관심이 빠르게 증가하고 있 다. 그럼에도 불구하고 여전히 $\mathrm{Pb}-\mathrm{Sn}$ 페로브스카이트는 $\mathrm{Pb}-\mathrm{Sn}$ alloying으로 인하여 순수 $\mathrm{Pb}$ 기반 조성과 내/외 적 특성에 있어서 많은 차이점을 보이고 있다. 그로 인하 여 소자로 적용 시, 낮은 구동 안정성, 낮은 결함 관용도, 밴드갭 대비 낮은 전류 밀도 등이 문제로 나타나고 있다. 특히, 안정성은 좁은 밴드갭의 $\mathrm{Pb}-\mathrm{Sn}$ 페로브스카이트 기반 소자가 가장 우선적으로 해결해야 할 문제로, 이러 한 낮은 구동 안정성은 소자 효율의 인증이나 페로브스카 이트-페로브스카이트 적층형 태양전지로의 적용 등을 방해하는 요소로 작용하게 된다. Stanford 대학의 $\mathrm{McGehee}$ 교수 연구팀은 $\mathrm{Pb}-\mathrm{Sn}$ 페로브스카이트의 안 정성 문제에 관련하여 많은 연구를 진행한 선도 그룹으로 써, 특히, 순수 $\mathrm{Sn}$ 기반의 $\mathrm{FASnI}_{3}$ 페로브스카이트에 $\mathrm{Pb}$ 를 치환하여 $\mathrm{FASn}_{\mathrm{x}} \mathrm{Pb}_{1-\mathrm{x}} \mathrm{I}_{3}$ 의 $\mathrm{Pb}-\mathrm{Sn}$ 페로브스카이트를 형성했을 때, 소재 내의 $\mathrm{Sn}^{2+}$ 가 산화되는 메커니즘에 대 한 분석을 통하여 상대적으로 높은 열과 산화 반응 안정 성을 확보할 수 있는 조성에 대한 기준점을 제시하였 다. ${ }^{36)} \mathrm{FASnI}_{3}$ 페로브스카이트에서는 $\mathrm{Sn}^{2+}$ 가 $\mathrm{SnO}_{2}$ 와 $\mathrm{SnI}_{4}$ 로 산화됨으로써 $\mathrm{Sn}^{2+}$ 결함뿐만 아니라 iodide 결함
을 동시에, 빠르게 야기시킨다. 그러나 $\mathrm{Pb}$ 치환을 통하여 alloy를 형성함으로써 산화 반응의 결과물로써 $\mathrm{I}_{2}, \mathrm{SnO}_{2}$, $\mathrm{PbI}_{2}$ 가 생성됨을 확인하였으며, 산화 반응 속도가 훨씬 느린 $\mathrm{Pb}$ 가 $\mathrm{Sn}$ 주변에 존재함으로써 산화 반응 속도 자체 를 늦춘다는 것을 확인하였다. 이는 $85^{\circ} \mathrm{C}$ 대기 중에서 보 관한 $\mathrm{Sn}$ 과 $\mathrm{Pb}-\mathrm{Sn}$ 기반 페로브스카이트의 주결정면의 XRD peak (100 면)의 변화를 통하여 확인할 수 있다. (Fig. 15-(a)) Yan 교수 연구팀은 $\mathrm{Pb}-\mathrm{Sn}$ 페로브스카이 트와 $\mathrm{Pb}$ 페로브스카이트의 dark current 비교 분석을 통 하여, $\mathrm{Pb}-\mathrm{Sn}$ 페로브스카이트가 상대적으로 높은 dark saturation current density $\left(J_{0}\right)$ 값과 높은 ideality factor를 지니고 있음을 보고하였다. (Fig. 15-(b) $)^{37)}$ Conductive atomic force microscopy (c-AFM)과 kelvin probe force microscopy (KPFM) 분석을 통하여 높은 결정립계에서 누수 전류(leakage current)가 크게 존재함을 확인하였고, $\mathrm{Br}$ 을 소량 첨가함으로써 결정립계 에 존재하는 결함을 효과적으로 passivation 하였다. $\mathrm{Br}$ 첨가를 통하여 $J_{0}$ 값을 4-5 order 이상 감소시킬 수 있 었고 이를 소자에 적용하여 $19 \%$ 이상의 고효율의 좁은 밴 드갭 태양전지 소자를 제작하였다. 무엇보다 주목할 점으 로, 결정립계에 존재하는 결함을 passivation을 함으로 써, $1.27 \mathrm{eV}$ 밴드갭에서의 개방 전압 $\left(V_{\mathrm{oc}}\right)$ 결핍을 0.384 $\mathrm{V}$ 로 줄일 수 있게 되었다.

\section{5. 접합 태양전지용 전자-정공 재결합용 투명 전극 소재}

2 터미널 접합 태양전지에서는 상부-하부 소자를 접합 하기 위해 Fig. 16와 같은 터널 접합층 혹은 투명전극 형 태의 전하-정공 재결합층이 사용된다. 터널 접합층은 고 도핑된 n-type 및 p-type 박막층을 이용하여 pn접합을 형성하고 각각 전자와 정공이 재결합할 수 있게 하여 전 하적 중성이 유지되며, 재결합층은 고전도도의 투명전극 층을 수십 $\mathrm{nm}$ 두께로 증착하여 각 하위 소자에서 생성된 전자와 정공이 재결합하도록 한다. 고효율의 접합 태양전 지를 위한 interlayer 연구에서 중요한 점은 높은 투과도 및 낮은 직렬 저항이다. 재결합을 위해 필요 이상의 두꺼 


\section{특 집 뚜 박익재, 김동회}
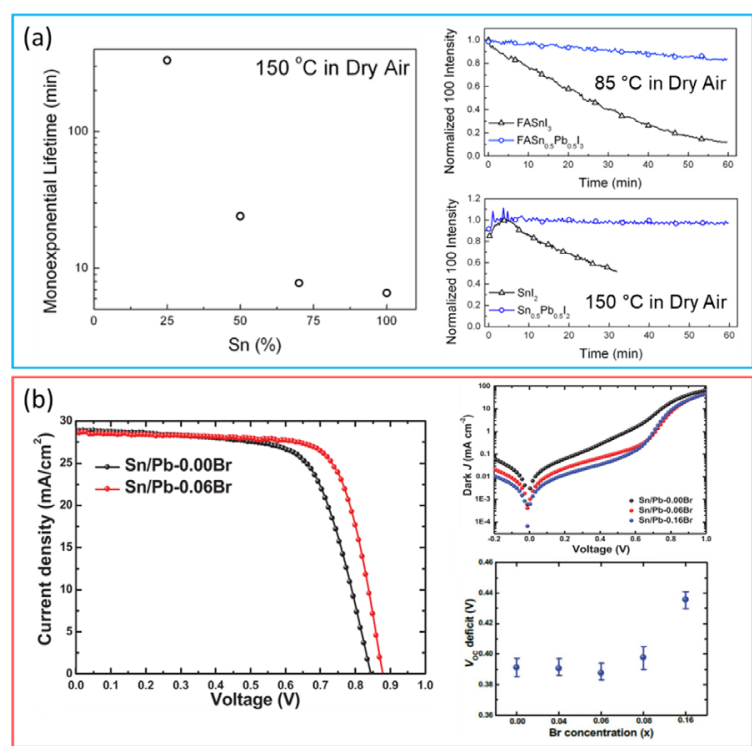

Fig. 15. $\mathrm{Pb}-\mathrm{Sn}$ 페로브스카이트의 안정성 및 내부 결함 개선을 위 한 연구 결과. (a) $\mathrm{Pb}-\mathrm{Sn}$ alloy 형성이 열 및 산소 안정성 에 미치는 영향,36) (b) $1-\mathrm{Br}$ alloy 형성 시 $\mathrm{Pb}-\mathrm{Sn}$ 페로브스카 이트 내부 결함에 미치는 영향과 이와 관련된 소자 특성. ${ }^{37}$

운 박막을 형성하게 되면 interlayer에 의한 광흡수가 증 가하여 하부 소자로 입사되는 광자 수가 감소하게 된다. 또한 직렬 접합의 특성 상 interlayer의 직렬 저항은 접 합 태양전지의 직렬 저항에 직접적인 영향을 미치기 때문 에 낮은 저항이 요구된다. 따라서 효율적인 전자-정공 재결합을 위한 최적의 두께 조건을 찾는 것이 중요하다.

투명 전극을 이용한 재결합층은 주로 상온에서 radio frequency $(\mathrm{RF})$ sputtering 방법으로 증착 가능한 비정 질 ITO나 IZO (indium zinc oxide)가 사용되었다. ${ }^{19,}{ }^{21}$, 26) 광에 의한 전하 수집을 위한 상부 투명 전극층과는 다
르게 수평 방향의 저항이 중요하지 않기 때문에 10-20 $\mathrm{nm}$ 두께만으로도 가능하다. 투명 전극을 이용한 박막 증 착은 터널 접합에 비해 디자인 및 구현이 쉬워 적용이 용 이한 장점이 있지만 2 터미널 페로브스카이트-페로브스 카이트 적층형 태양전지에 적용할 경우에는 스퍼터링에 의해 하부 페로브스카이트 소자에 가해질 수 있는 데미지 를 막아줄 적절한 보호층이 필요하다. 앞서 소개한 많은 그룹에서 atomic layer deposition (ALD)을 이용하여 수 나노미터 두께의 산화물을 증착하여 보호층으로 사용 하였다. ${ }^{11,12,19,21,26)}$

일반적인 2 터미널 페로브스카이트-페로브스카이트 적층형 태양전지 연구들은 용액 공정 기반이기 때문에 재 결합층은 전자-정공의 재결합뿐만 아니라 용액이 상부 소자로 침투하는 것을 보호해 줄 수 있는 보호층의 역할 을 해야 한다. 보호층이 없으면 하부 소자 공정 시 상부 소자의 페로브스카이트 층이 용액에 의해 용해된다. 기존 의 투명 전극은 $100 \mathrm{~nm}$ 수준의 두께를 확보해야 충분히 용액 공정으로부터의 보호층 역할을 할 수 있기 때문에 높은 수평 전도도로 인해 shunt path가 생길 확률이 증 가하고 하부 소자의 광전류 밀도 감소를 야기한다. 하지 만, 최근 미국 NREL 연구팀은 Fig. 17와 같이 $\mathrm{C}_{60}$ 전자 수송층 상부에 $1 \mathrm{~nm}$ 두께의 초박막 poly (ethylenimine) ethoxylated (PEIE) 및 ALD를 이용한 AZO (aluminium zinc oxide) 층을 도입하여 스퍼터 및 용액 공정에 의한 데미지를 방지할 수 있는 보호층을 개발하였다. ${ }^{11)}$ 초박막 PEIE 층은 ALD 공정 시 nucleation 및 금속 유기 전구 체와의 반응을 원활하게 시작할 수 있게 하여 대조군 대 비 큰 $\mathrm{AZO}$ 결정판을 성장시키고 coverage를 향상시켰

(b)

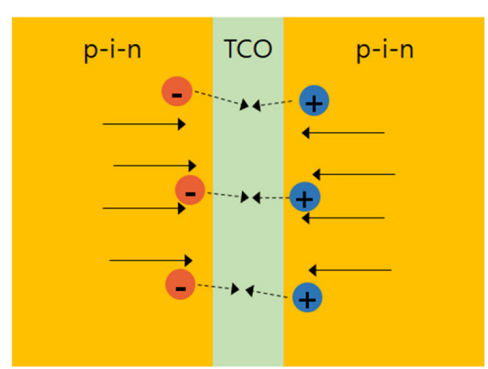

Fig. 16. (a) $n^{+1} / p^{++}$Si을 이용한 터널 접합층22) 및 (b) 투명전도성막(TCO)를 이용한 재결합층 

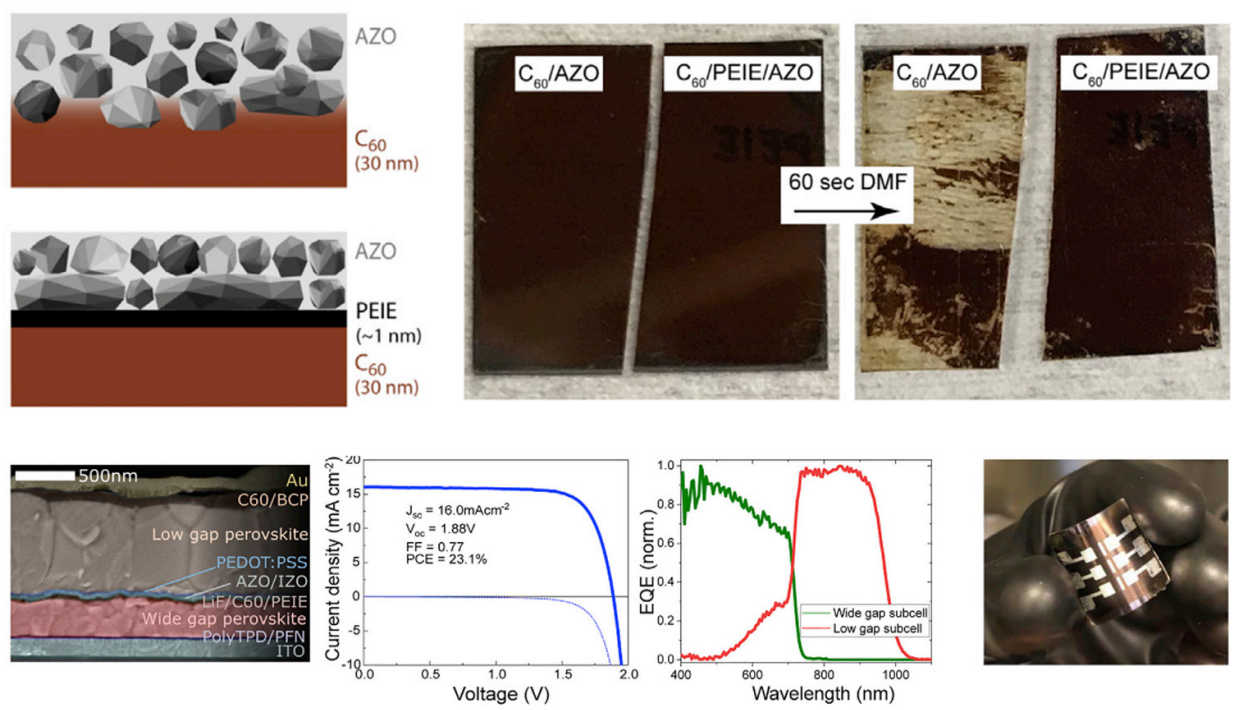

Fig. 17. PEIE를 통해 개선된 ALD 공정 및 AZO 층이 도입된 유연 2 터미널 페로브스카이트-페로브스카이트 적층형 태양전지 ${ }^{11}$

다. 이를 통하여 5-15 nm 두께의 IZO 재결합층 만으로 용액 공정으로 인한 데미지를 막는 것이 가능해졌다.

적층형 태양전지는 상술한 바와 같이 상-하부 소자 중 낮은 광전류 밀도가 적층형 소자의 광전류 밀도를 결정하 기 때문에, 측정에 사용되는 솔라시뮬레이터의 스펙트럼 이 실제 태양광의 스펙트럼과 불일치할 경우 전체 광량을 정확히 calibration 하더라도 스펙트럼 미스매치에 따라 상-하부 소자의 광전류 밀도가 달라져 실제 소자 특성 평 가에 어려움이 있을 수 있다. 따라서 오차의 정도를 파악 하고 보정하는 기술이 필요하다. 페로브스카이트-실리 콘 적층형 소자에서 투명 전극을 도입할 경우 재결합층을 외부로 노출시켜 추가적인 전극으로 활용할 수 있다. 최 근 서울대학교 김진영 교수팀은 적층형 소자의 정확한 특 성 평가를 위한 3 터미널 구조의 페로브스카이트/실리콘 적층형 소자를 보고하였다. ${ }^{21)} \mathrm{Fig}$. 18 에서 나온 것과 같 이 2 터미널 적층형 태양전지의 $\mathrm{EQE}$ 를 정확히 측정하기 위해서는 적절한 light bias 및 potential bias 가 필요하 지만 재결합층을 중간 전극으로 이용하면 상하부 하위 소 자의 $\mathrm{EQE}$ 를 bias 없이도 각각 측정이 가능하다. 또한 각 각의 하위 소자의 $J-V$ 곡선을 얻을 수 있기 때문에 실제 태양광과 실험실에서 사용하는 솔라시뮬레이터 광원의 스펙트럼 차이에서 발생하는 $\mathrm{EQE} / J-V$ 곡선 간의 광전
류 밀도 오차도 확인 가능하다.

터널 접합의 경우 투명 전극을 이용한 재결합층과 비교 하여 수평 방향의 저항이 크기 때문에 상대적으로 shunt path의 발생으로 인한 충진율 저하를 방지할 수 있는 장 점이 있다. 2018년 스위스 EPFL의 Ballif 그룹에서는 plasma-enhanced CVD (PECVD)로 증착된 n-type/ $\mathrm{p}$-type의 나노결정질 실리콘 층을 터널 접합으로 도입 하였다. ${ }^{7}$ 텍스쳐 실리콘 하부 소자을 사용했기 때문에 shunt path에 의한 상부 소자 쇼트를 방지하는 기술이 중요하다. $\mathrm{ITO}$ 를 재결합층으로 쓴 경우 상부소자가 쇼트 인 반면 터널 접합을 사용함에 따라 $1780 \mathrm{mV}$ 의 높은 광 전압을 나타냈다. 또한, 호주 UNSW 대학의 Ho-Baillie 그룹에서 $\mathrm{SnO}_{2}$ 와 $\mathrm{p}^{++}$emitter를 이용한 터널 접합층을 페로브스카이트-실리콘 적층형 소자에 도입하였다. Ho-Baillie 그룹은 $\mathrm{p}^{++}$emitter의 농도에 따른 전류-전 압 곡선을 시뮬레이션을 통해 예측하고 실제 소자로 구현 하여 $16 \mathrm{~cm}^{2}$ 면적에서 $17 \%$ 의 효율을 달성하였고 후속 연 구를 통해 $21.8 \%$ 의 효율을 달성했다. ${ }^{20,38)}$

\section{6. 결론 및 전망}

페로브스카이트 소재는 조성에 따른 밴드갭 유연성과 

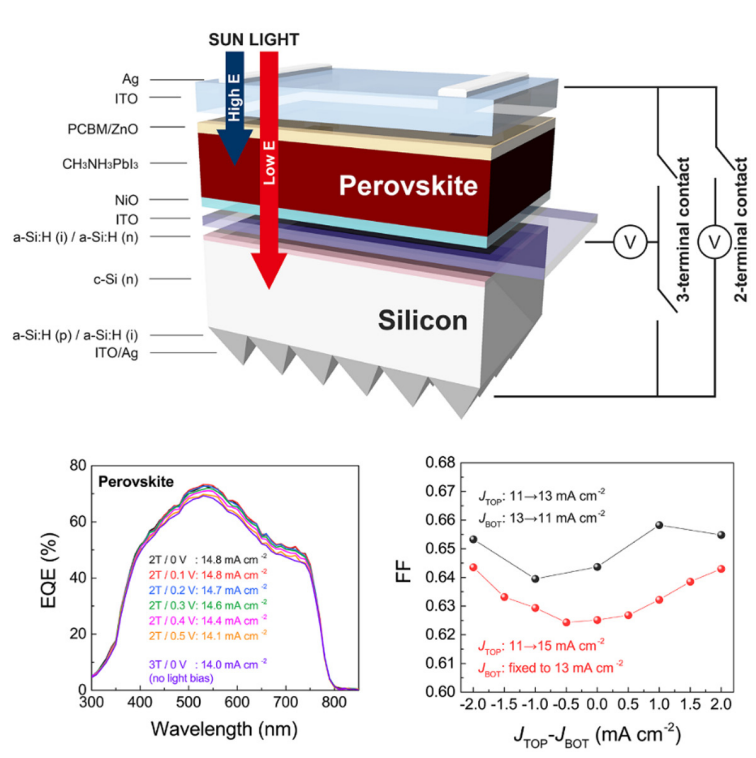

Fig. 18. 3 터미널 구조의 페로브스카이트-실리콘 태양전지 모식도, potential bias에 따른 상부 소자의 EQE 곡선 변화 및 상-하 부 소자 간 광전류 미스매치에 따른 적층형 태양전지의 충 진율 경향 곡선211

더불어 낮은 공정 온도, 용액 및 진공 공정 등의 높은 공 정 자유도로 인하여 실리콘, CIGS 등의 기존 태양전지와 적층 태양전지를 형성하기 적합한 소재로 많은 관심을 가 지고 연구되어 왔다. 이후 좁은 밴드갭 페로브스카이트 연구가 활성화됨에 따라서, 자연스럽게 페로브스카이트 만을 적용한 적층형 태양전지 연구도 진행되었다. 이는 이전에 볼 수 없었던 다양한 광흡수체의 조합과 구조의 적층형 태양전지 연구로 이어졌다. 따라서 페로브스카이 트를 이용한 적층형 태양전지 연구는 빛을 흡수하는 우수 한 페로브스카이트 혹은 다른 광 흡수 소재를 시작으로 각 소자에서 생성된 전자와 정공을 수집할 수 있는 수집 층과 소자 사이를 연결하는 재결합층 등 적층형 태양전지 의 모든 구성 요소의 소재 선택부터 공정에 이르기까지 태양전지를 연구하는 많은 과학자들에게 새로운 영역을 개척하게 끔 이끌었다. 그 결과, $1.25 \mathrm{eV}$ 부터 $1.7 \mathrm{eV}$ 에 이르는 다양한 밴드갭의 페로브스카이트 개발과 이를 기 반으로 한 고효율 소자 구현, 전도도가 뛰어나며 공정 적 용성이 탁월한 재결합층 개발에 이르기까지 의미 있는 연 구 결과들이 보고 되었다. 적층형 소재 연구는 최근 3 년
동안 빠르게 효율 증가를 이뤼 페로브스카이트-실리콘 의 경우 $28 \%$ 의 높은 인증 효율을 달성했고, 저비용 공정 기반으로는 최초로 $30 \%$ 이상의 효율 달성을 목전에 두고 있다. 이처럼 급진적이면서도 우수한 결과에도 불구하고 넓은 밴드갭 페로브스카이트에서의 전압 결핍과 좁은 밴 드갭 페로브스카이트에서의 낮은 안정성 및 광전류 밀도 문제 등 여전히 많은 부분에서 해결해야 할 문제들이 남 아있다. 또한 고효율 이종/동종 소재 기반의 적층형 태양 전지에 적용할 수 있는 터널 접합층에 관한 체계적이고 추가적인 연구 역시 필요하다. 나아가 이러한 적층형 태 양전지가 양산에 도달할 수 있도록 적층형 태양전지 기술 의 대면적 모듈화 역시 반드시 고려해야 할 연구 분야이 다. 그러나 본 논문에서 소개한 것과 같이 기존에 풀리지 않을 것 같았던 많은 문제점들이 전세계의 훌륭한 연구진 들에 의해 해결되었고, 새로운 방향이 끊임없이 제시되고 있기 때문에 남아있는 문제점들 역시 해결될 것으로 예상 한다. 따라서 멀지 않은 시기에 페로브스카이트를 기반으 로 한 적층형 태양전지 소자가 $35 \%$ 이상의 고효율을 달 성할 것으로 기대한다.

\section{Acknowledgement}

이 논문은 2019년도 세종대학교에서 재원을 지원받아 수행된 연구임 (No. 20190390)

\section{참고문헌}

1. S. Nowak, "Trends 2018 in Photovoltaic Applications," IEA International Energy Agency, Sweden, (2018)

2. https://www.nrel.gov/pv/assets/images/efficiencychart.png

3. A. Kojima, K. Teshima, Y. Shirai and T. Miyasaka, "Organometal Halide Perovskites as Visible-Light Sensitizers for Photovoltaic Cells," J. Am. Chem. Soc. 131 [17] 6050-1 (2009)

4. M. Yang, Z. Li, M. O. Reese, O. G. Reid, D. H. Kim, S. Siol, T. R. Klein, Y. Yan, J. J. Berry, M. F. A. M. van Hest and $\mathrm{K}$. Zhu, "Perovskite Ink with Wide Processing Window for Scalable High-Efficiency Solar Cells," Nat. Energy 2 [5] 17038 (2017)

5. H. S. K. W. S. Han, B. S. Choi, D. K. Oh, "차세대 고 
효율 태양전지 기술 동향," 전자통신동향분석 22 [5] 86-94 (2007)

6. T. Leijtens, K. A. Bush, R. Prasanna and M. D. McGehee, "Opportunities and Challenges for Tandem Solar Cells Using Metal Halide Perovskite Semiconductors," Nat. Energy 1 (2018)

7. F. Sahli, J. Werner, B. A. Kamino, M. Bräuninger, R. Monnard, B. Paviet-Salomon, L. Barraud, L. Ding, J. J. D. Leon and D. Sacchetto, "Fully Textured Monolithic Perovskite/Silicon Tandem Solar Cells with 25.2\% Power Conversion Efficiency," Nat. Mater. 1 (2018)

8. Q. Han, Y.-T. Hsieh, L. Meng, J.-L. Wu, P. Sun, E.-P. Yao, S.-Y. Chang, S.-H. Bae, T. Kato, V. Bermudez and Y. Yang, "High-Performance Perovskite/Cu(in, Ga)Se〈Sub〉2〈/Sub〉 Monolithic Tandem Solar Cells," Science 361 [6405] 904-8 (2018)

9. D. H. Kim, C. P. Muzzillo, J. Tong, A. F. Palmstrom, B. W. Larson, C. Choi, S. P. Harvey, S. Glynn, J. B. Whitaker, F. Zhang, Z. Li, H. Lu, M. F. A. M. van Hest, J. J. Berry, L. M. Mansfield, Y. Huang, Y. Yan and K. Zhu, "Bimolecular Additives Improve WideBand-Gap Perovskites for Efficient Tandem Solar Cells with Cigs," Joule (2019)

10. G. E. Eperon, T. Leijtens, K. A. Bush, R. Prasanna, T. Green, J. T.-W. Wang, D. P. McMeekin, G. Volonakis, R. L. Milot, R. May, A. F. Palmstrom, D. J. Slotcavage, R. A. Belisle, J. B. Patel, E. S. Parrott, S. R. J., W. Ma, F. Moghadam, B. Conings, A. Babayigit, H. -G. Boyen, S. Bent, F. Giustion, L. M. Herz, M. B. Johnston, M. D. McGehee and H. J. Snaith, "Perovskite-Perovskite Tandem Photovoltaics with Optimized Bandgaps," Science aaf 9717 (2016)

11. A. F. Palmstrom, G. E. Eperon, T. Leijtens, R. Prasanna, S. N. Habisreutinger, W. Nemeth, E. A. Gaulding, S. P. Dunfield, M. Reese, S. Nanayakkara, T. Moot, J. Werner, J. Liu, B. To, S. T. Christensen, M. D. McGehee, M. F. A. M. van Hest, J. M. Luther, J. J. Berry and D. T. Moore, "Enabling Flexible AllPerovskite Tandem Solar Cells," Joule (2019)

12. J. Tong, Z. Song, D. H. Kim, X. Chen, C. Chen, A. F. Palmstrom, P. F. Ndione, M. O. Reese, S. P. Dunfield, O. G. Reid, J. Liu, F. Zhang, S. P. Harvey, Z. Li, S. T. Christensen, G. Teeter, D. Zhao, M. M. Al-Jassim, M. F. A. M. van Hest, M. C. Beard, S. E. Shaheen, J. J. Berry, Y. Yan and K. Zhu, "Carrier Lifetimes of \&Gt;1 Ms in Sn-Pb Perovskites Enable Efficient All-
Perovskite Tandem Solar Cells," Science 364 [6439] 475-9 (2019)

13. H. -S. Kim, C.-R. Lee, J.-H. Im, K.-B. Lee, T. Moehl, A. Marchioro, S.-J. Moon, R. HumphryBaker, J.-H. Yum, J. E. Moser, M. Grätzel and N. -G. Park, "Lead Iodide Perovskite Sensitized AllSolid-State Submicron Thin Film Mesoscopic Solar Cell with Efficiency Exceeding 9\%," Sci. Rep. 2591 (2012)

14. M. M. Lee, J. Teuscher, T. Miyasaka, T. N. Murakami and H. J. Snaith, "Efficient Hybrid Solar Cells Based on Meso-Superstructured Organometal Halide Perovskites," Science 338 [6107] 643-7 (2012)

15. T. Duong, Y. Wu, H. Shen, J. Peng, X. Fu, D. Jacobs, E. C. Wang, T. C. Kho, K. C. Fong and M. Stocks, "Rubidium Multication Perovskite with Optimized Bandgap for Perovskite Silicon Tandem with over 26\% Efficiency," Adv. Energy Mater. 7 [14] 1700228 (2017)

16. E. T. Hoke, D. J. Slotcavage, E. R. Dohner, A. R. Bowring, H. I. Karunadasa and M. D. McGehee, "Reversible Photo-Induced Trap Formation in MixedHalide Hybrid Perovskites for Photovoltaics," Chem. Sci. 6 [1] 613-7 (2015)

17. T. C.-J. Yang, P. Fiala, Q. Jeangros and C. Ballif, "High-Bandgap PerovskiteMaterials for Multijunction Solar Cells," Joule 2 [8] 1421-36 (2018)

18. D. P. McMeekin, G. Sadoughi, W. Rehman, G. E. Eperon, M. Saliba, M. T. Hörantner, A. Haghighirad, N. Sakai, L. Korte, B. Rech, M. B. Johnston, L. M. Herz and H. J. Snaith, "A Mixed-Cation Lead MixedHalide Perovskite Absorber for Tandem Solar Cells," Science 351 [6269] 151-5 (2016)

19. K. A. Bush, A. F. Palmstrom, Z. J. Yu, M. Boccard, R. Cheacharoen, J. P. Mailoa, D. P. McMeekin, R. L. Z. Hoye, C. D. Bailie, T. Leijtens, I. M. Peters, M. C. Minichetti, N. Rolston, R. Prasanna, S. Sofia, D. Harwood, W. Ma, F. Moghadam, H. J. Snaith, T. Buonassisi, Z. C. Holman, S. F. Bent and M. D. McGehee, "23.6\%-Efficient Monolithic Perovskite/ Silicon Tandem Solar Cells with Improved Stability," Nat. Energy 2 [4] 17009 (2017)

20. J. Zheng, C. F. J. Lau, H. Mehrvarz, F.-J. Ma, Y. Jiang, X. Deng, A. Soeriyadi, J. Kim, M. Zhang, L. Hu, X. Cui, D. S. Lee, J. Bing, Y. Cho, C. Chen, M. A. Green, S. Huang and A. W. Y. Ho-Baillie, "Large Area Efficient Interface Layer Free Monolithic Perovskite/Homo-Junction-Silicon Tandem Solar 
Cell with over 20\% Efficiency," Energy Environ. Sci. 11 [9] 2432-43 (2018)

21. I. J. Park, J. H. Park, S. G. Ji, M.-A. Park, J. H. Jang and J. Y. Kim, "A Three-Terminal Monolithic Perovskite/Si Tandem Solar Cell Characterization Platform," Joule 3 [3] 807-18 (2019)

22. J. P. Mailoa, C. D. Bailie, E. C. Johlin, E. T. Hoke, A. J. Akey, W. H. Nguyen, M. D. McGehee and T. Buonassisi, "A 2-Terminal Perovskite/Silicon Multijunction Solar Cell Enabled by a Silicon Tunnel Junction," Appl. Phys. Lett. 106 [12] 121105 (2015)

23. J. Werner, C. H. Weng, A. Walter, L. Fesquet, J. P. Seif, S. De Wolf, B. Niesen and C. Ballif, "Efficient Monolithic Perovskite/Silicon Tandem Solar Cell with Cell Area $>1$ Cm(2)," J. Phys. Chem. Lett. 7 [1] 161-6 (2016)

24. J. Werner, L. Barraud, A. Walter, M. Bräuninger, F. Sahli, D. Sacchetto, N. Tétreault, B. Paviet-Salomon, S.-J. Moon, C. Allebé, M. Despeisse, S. Nicolay, S. De Wolf, B. Niesen and C. Ballif, "Efficient nearInfrared-Transparent Perovskite Solar Cells Enabling Direct Comparison of 4-Terminal and Monolithic Perovskite/Silicon Tandem Cells," ACS Energy Lett. 1 [2] 474-80 (2016)

25. K. A. Bush, S. Manzoor, K. Frohna, Z. J. Yu, J. A. Raiford, A. F. Palmstrom, H.-P. Wang, R. Prasanna, S. F. Bent, Z. C. Holman and M. D. McGehee, "Minimizing Current and Voltage Losses to Reach 25\% Efficient Monolithic Two-Terminal PerovskiteSilicon Tandem Solar Cells," ACS Energy Lett. 217380 (2018)

26. B. Chen, Z. Yu, K. Liu, X. Zheng, Y. Liu, J. Shi, D. Spronk, P. N. Rudd, Z. Holman and J. Huang, "Grain Engineering for Perovskite/Silicon Monolithic Tandem Solar Cells with Efficiency of 25.4\%," Joule 3 [1] 177-90 (2019)

27. F. Hao, C. C. Stoumpos, R. P. H. Chang and M. G. Kanatzidis, "Anomalous Band Gap Behavior in Mixed $\mathrm{Sn}$ and $\mathrm{Pb}$ Perovskites Enables Broadening of Absorption Spectrum in Solar Cells," J. Am. Chem. Soc. 136 [22] 8094-9 (2014)

28. J. Im, C. C. Stoumpos, H. Jin, A. J. Freeman and M. G. Kanatzidis, "Antagonism between Spin-Orbit Coupling and Steric Effects Causes Anomalous Band Gap Evolution in the Perovskite Photovoltaic Materials Ch3nh3sn1-Xpbxi3," J. Phys. Chem. Lett. 6 [17] 3503-9 (2015)

29. T. M. Koh, T. Krishnamoorthy, N. Yantara, C. Shi,
W. L. Leong, P. P. Boix, A. C. Grimsdale, S. G. Mhaisalkar and N. Mathews, "Formamidinium TinBased Perovskite with Low Eg for Photovoltaic Applications," J. Mater. Chem. A 3 [29] 14996-5000 (2015)

30. S. J. Lee, S. S. Shin, Y. C. Kim, D. Kim, T. K. Ahn, J. H. Noh, J. Seo and S. I. Seok, "Fabrication of Efficient Formamidinium Tin Iodide Perovskite Solar Cells through Snf2-Pyrazine Complex," J. Am. Chem. Soc. 138 [12] 3974-7 (2016)

31. W. Liao, D. Zhao, Y. Yu, N. Shrestha, K. Ghimire, C. R. Grice, C. Wang, Y. Xiao, A. J. Cimaroli, R. J. Ellingson, N. J. Podraza, K. Zhu, R. -G. Xiong and Y. Yan, "Fabrication of Efficient Low-Bandgap Perovskite Solar Cells by Combining Formamidinium Tin Iodide with Methylammonium Lead Iodide," $J$. Am. Chem. Soc. 138 [38] 12360-3 (2016)

32. R. Prasanna, A. Gold-Parker, T. Leijtens, B. Conings, A. Babayigit, H. G. Boyen, M. F. Toney and M. D. McGehee, "Band Gap Tuning Via Lattice Contraction and Octahedral Tilting in Perovskite Materials for Photovoltaics," J. Am. Chem. Soc. 139 [32] 11117-24 (2017)

33. D. Zhao, Y. Yu, C. Wang, W. Liao, N. Shrestha, C. R. Grice, A. J. Cimaroli, L. Guan, R. J. Ellingson, K. Zhu, X. Zhao, R.-G. Xiong and Y. Yan, "LowBandgap Mixed Tin-Lead Iodide Perovskite Absorbers with Long Carrier Lifetimes for AllPerovskite Tandem Solar Cells," Nat. Energy 2 [4] 17018 (2017)

34. D. Zhao, C. Chen, C. Wang, M. M. Junda, Z. Song, C. R. Grice, Y. Yu, C. Li, B. Subedi, N. J. Podraza, X. Zhao, G. Fang, R.-G. Xiong, K. Zhu and Y. Yan, "Efficient Two-Terminal All-Perovskite Tandem Solar Cells Enabled by High-Quality Low-Bandgap Absorber Layers," Nat. Energy 3 [12] 1093-100 (2018)

35. T. Leijtens, R. Prasanna, K. A. Bush, G. E. Eperon, J. A. Raiford, A. Gold-Parker, E. J. Wolf, S. A. Swifter, C. C. Boyd, H.-P. Wang, M. F. Toney, S. F. Bent and M. D. McGehee, "Tin-Lead Halide Perovskites with Improved Thermal and Air Stability for Efficient All-Perovskite Tandem Solar Cells," Sustainable Energy Fuels 2 [11] 2450-9 (2018)

36. T. Leijtens, R. Prasanna, A. Gold-Parker, M. F. Toney and M. D. McGehee, "Mechanism of Tin Oxidation and Stabilization by Lead Substitution in Tin Halide Perovskites," ACS Energy Lett. 2 [9] 215965 (2017) 
37. C. Li, Z. Song, D. Zhao, C. Xiao, B. Subedi, N. Shrestha, M. M. Junda, C. Wang, C.-S. Jiang, M. Al-Jassim, R. J. Ellingson, N. J. Podraza, K. Zhu and Y. Yan, "Reducing Saturation-Current Density to Realize High-Efficiency Low-Bandgap Mixed Tin - Lead Halide Perovskite Solar Cells," Adv. Energy Mater. 9 [3] 1803135 (2019)

38. J. Zheng, H. Mehrvarz, F.-J. Ma, C. F. J. Lau, M. A. Green, S. Huang and A. W. Y. Ho-Baillie, "21.8\% Efficient Monolithic Perovskite/Homo-JunctionSilicon Tandem Solar Cell on 16 Cm2," ACS Energy Lett. 3 [9] 2299-300 (2018)

39. C. D. Bailie, M. G. Christoforo, J. P. Mailoa, A. R. Bowring, E. L. Unger, W. H. Nguyen, J. Burschka, N. Pellet, J. Z. Lee and M. Grätzel, "Semi-Transparent Perovskite Solar Cells for Tandems with Silicon and Cigs," Energy Environ. Sci. 8 [3] 956-63 (2015)

40. Y. Wu, D. Yan, J. Peng, T. Duong, Y. Wan, S. P. Phang, H. Shen, N. Wu, C. Barugkin, X. Fu, S. Surve, D. Grant, D. Walter, T. P. White, K. R. Catchpole and K. J. Weber, "Monolithic Perovskite/ Silicon-Homojunction Tandem Solar Cell with over 22\% Efficiency," Energy Environ. Sci. 10 [11] 2472-9 (2017)

41. F. Sahli, B. A. Kamino, J. Werner, M. Bräuninger, B. Paviet-Salomon, L. Barraud, R. Monnard, J. P. Seif, A. Tomasi, Q. Jeangros, A. Hessler-Wyser, S. De Wolf, M. Despeisse, S. Nicolay, B. Niesen and C. Ballif, "Improved Optics in Monolithic Perovskite/

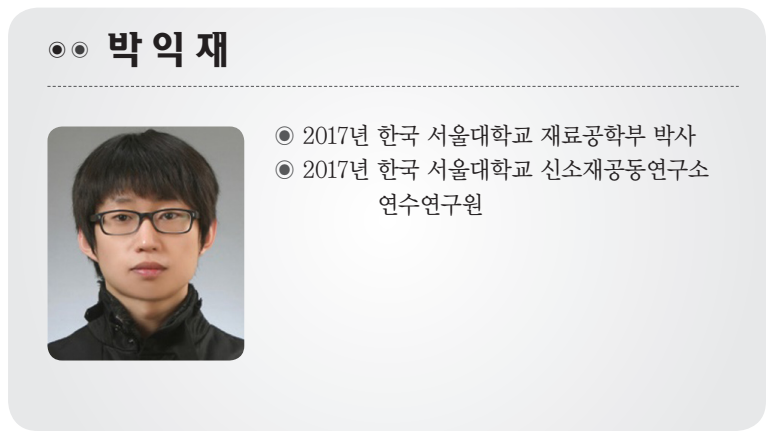

Silicon Tandem Solar Cells with a Nanocrystalline Silicon Recombination Junction," Adv. Energy Mater. 8 [6] 1701609 (2018)

42. S. Albrecht, M. Saliba, J. P. Correa Baena, F. Lang, L. Kegelmann, M. Mews, L. Steier, A. Abate, J. Rappich, L. Korte, R. Schlatmann, M. K. Nazeeruddin, A. Hagfeldt, M. Grätzel and B. Rech, "Monolithic Perovskite/Silicon-Heterojunction Tandem Solar Cells Processed at Low Temperature," Energy Environ. Sci. 9 [1] 81-8 (2016)

43. D. Zhao, C. Wang, Z. Song, Y. Yu, C. Chen, X. Zhao, K. Zhu and Y. Yan, "Four-Terminal All-Perovskite Tandem Solar Cells Achieving Power Conversion Efficiencies Exceeding 23\%," ACS Energy Lett. 3 [2] 305-6 (2018)

44. A. Rajagopal, Z. Yang, S. B. Jo, I. L. Braly, P. W. Liang, H. W. Hillhouse and A. K. Jen, "Highly Efficient Perovskite-Perovskite Tandem Solar Cells Reaching $80 \%$ of the Theoretical Limit in Photovoltage," Adv. Mater. 29 [34] (2017)

45. D. Forgács, L. Gil-Escrig, D. Pérez-Del-Rey, C. Momblona, J. Werner, B. Niesen, C. Ballif, M. Sessolo and H. J. Bolink, "Efficient Monolithic Perovskite/ Perovskite Tandem Solar Cells," Adv. Energy Mater. 7 [8] 1602121 (2017)

46. F. Jiang, T. Liu, B. Luo, J. Tong, F. Qin, S. Xiong, Z. $\mathrm{Li}$ and Y. Zhou, "A Two-Terminal Perovskite/ Perovskite Tandem Solar Cell," J. Mater. Chem. A 4 [4] 1208-13 (2016)

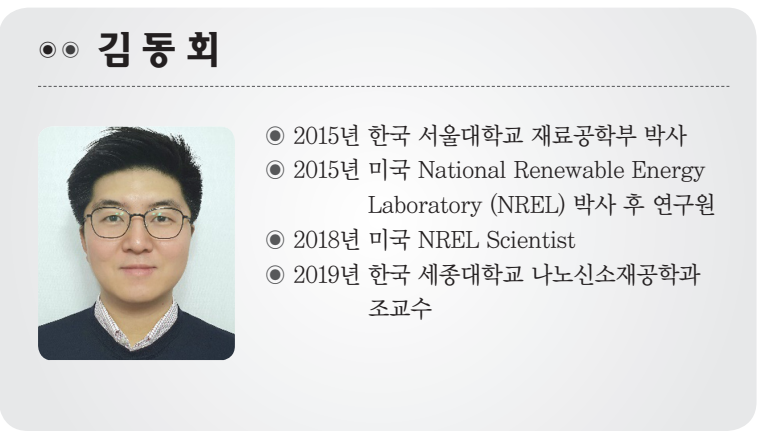

